\title{
ROBUST ESTIMATES OF CHANGES IN POVERTY AND INEQUALITY IN POST-INDEPENDENCE NAMIBIA
}

Sebastian Levine

UNDP

\section{Benjamin Roberts}

Human Sciences Research Council

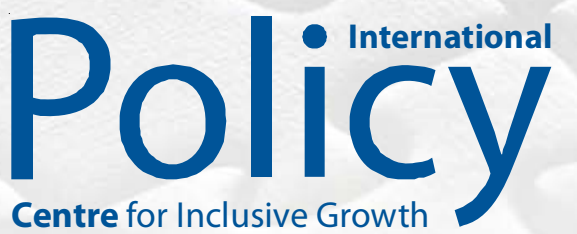


Copyright $\odot 2012$

International Policy Centre for Inclusive Growth

United Nations Development Programme

International Policy Centre for Inclusive Growth (IPC - IG)

Poverty Practice, Bureau for Development Policy, UNDP

Esplanada dos Ministérios, Bloco $0,7^{\circ}$ andar

70052-900 Brasilia, DF - Brazil

Telephone: +556121055000

E-mail: ipc@ipc-undp.org • URL: www.ipc-undp.org

The International Policy Centre for Inclusive Growth is jointly supported by the Poverty Practice, Bureau for Development Policy, UNDP and the Government of Brazil.

\section{Rights and Permissions}

All rights reserved.

The text and data in this publication may be reproduced as long as the source is cited. Reproductions for commercial purposes are forbidden.

The International Policy Centre for Inclusive Growth disseminates the findings of its work in progress to encourage the exchange of ideas about development issues. The papers are signed by the authors and should be cited accordingly. The findings, interpretations, and conclusions that they express are those of the authors and not necessarily those of the United Nations Development Programme or the Government of Brazil.

Working Papers are available online at www.ipc-undp.org and subscriptions can be requested by email to ipc@ipc-undp.org 


\title{
ROBUST ESTIMATES OF CHANGES IN POVERTY AND INEQUALITY IN
}

\author{
POST-INDEPENDENCE NAMIBIA
}

\author{
Sebastian Levine and Benjamin Roberts*
}

The authors estimate changes in the distribution of household consumption expenditure in Namibia since Independence in 1990 and the effects on poverty. To produce comparability between two household surveys, they use survey matching techniques and apply the framework of stochastic dominance to test the robustness of the results. The results reveal a significant decrease in the poverty headcount over the period and small but insignificant decreases in the country's extremely high levels of inequality. Decomposition analysis shows that poverty reduction in Namibia is largely driven by growth in mean incomes rather than redistribution. Even so, there have been important changes in inequality, especially between different social groups, as educational attainment has replaced ethnicity as the main determinant of inequality between groups.

JEL Classification: D31, I32, O55

Keywords: Sub-Saharan Africa, Namibia, Poverty, Inequality

\section{INTRODUCTION}

The economic, political and social transition of Namibia over the past two decades has been remarkable on many levels. From being mired in a protracted guerrilla war and after a century of colonial rule-until 1990 as a de facto annex to the South African Apartheid state-Namibia is now widely regarded as one of the more stable and well-governed democracies on the continent. Moreover, the country has replaced the economic stagnation and international isolation of the past with steady economic growth, fiscal prudence and international trade and cooperation. Today, Namibia is classified by the World Bank as an 'upper middle-income country' with a per capita GDP almost three times the average for sub-Saharan Africa. ${ }^{1}$

\footnotetext{
* Sebastian Levine, corresponding author: UNDP, Regional Bureau for Africa, One UN Plaza, New York, NY 10017. Tel: +1 (212) 906-5913. Email: sebastian.levine@undp.org and Benjamin Roberts, Human Sciences Research Council, 750 Francois Road, Durban, South Africa 4001.

In preparing this paper we have benefitted from comments and suggestions from Jean-Yves Duclos, Abdelkrim Araar, Shantanu Mukherjee, Neil McCulloch, Emma Samman, Nora Lustig and Ricardo Paes de Barros, as well as from participants at the UNU-WIDER conference on Frontiers of Poverty Analysis, 26-27 September 2008 in Helsinki, and the 7th General Meeting of the Poverty and Economic Policy Network, 10-12 December 2008 in Manila. We are grateful to the Central Bureau of Statistics in Windhoek for access to the survey data. We are also grateful for the comments from two anonymous reviewers. The paper was prepared for the UNDP project 'Markets, the State and the Dynamics of Inequality: How to Advance Inclusive Growth' with the Bureau for Development Policy and the Regional Bureau for Africa. Opinions expressed in the paper are those of the authors and not UNDP. Any errors or omissions are also our own. A revised version of the paper is forthcoming in the South African Journal of Economics.
} 
Nevertheless, because of extreme levels of inequality in household incomes, assets and capabilities, average GDP remains a particularly deceptive measure of welfare in Namibia. Extreme inequality in Namibia is mainly a result of economic and social structures that emerged during its colonial past, notably the high dependence on capital-intensive mineral extraction and the racial inequality perpetuated under German and South African rule (World Bank, 1993; United Nations, 2004). Two decades after Independence there is widespread concern, especially within Namibia itself, about the persistently high level of inequality and the possible impact on the country's continued transition (World Bank, 2005; National Planning Commission, 2004).

There are several reasons for this concern. First, sustained and high inequality is considered unacceptable on moral grounds, as it is taken as a failure by the democratic dispensation to deliver social justice and 'national reconciliation' and to effectively break with the country's racist and discriminatory past (Melber, 2005; Freeman, 1991). Second, there are fears that disparities could fuel social unrest, especially among disenfranchised groups of youth, and pose a threat to Namibia's treasured social and political stability (World Bank, 2005; Bauer 2001). Third, while the empirical evidence of causal linkages between inequality and economic growth are ambiguous (Lopez, 2005; Burguignon, 2004)_and Namibia has been able to produce above-average growth rates despite the high levels of initial inequalitythe impact of high inequality in terms of lowering the effectiveness of economic growth on poverty reduction is well established (Ravallion and Chen, 2003; Ravallion, 1997). This point is of particular concern to Namibian policymakers who have made reducing poverty and inequality core priorities in successive national development strategies (National Planning Commission, 2004). Finally, international aid agencies care about what has happened to inequality in Namibia as an indication of the effectiveness of the extensive technical and financial assistance bestowed upon one of Africa's youngest democracies.

Several studies have analysed changes in poverty and inequality in South Africa since the introduction of majority rule in that country (for example, Leibbrandt et al., 2010; Hoogeveen and Özler, 2006; Van der Berg et al., 2005). However, much less is known about Namibia's post-Independence experience. One reason for this is limitations in the available data and few efforts to overcome those limitations. Notably, important changes in the setting and in the methodologies applied in the two rounds of the official Namibia Household Income and Expenditure Survey (NHIES) in 1993/1994 and 2003/2004 have complicated direct comparison of household consumption expenditure (Levine and Roberts, 2008).

This lack of comparability of monetary welfare is a key challenge that this paper seeks to overcome. We do this by first deploying an extension of a new methodology to match monetary and non-monetary survey data and on that basis 'predict' household expenditure on the less reliable 1993/1994 baseline. This enables a comparison with the much stronger dataset from 2003/2004. Comparability issues of the kinds encountered in the NHIES are fairly common across African household survey programmes, which gives the methodology and application presented in this paper more general relevance.

In the presentation of empirical results we examine whether the extremely high level of initial income inequality in Namibia has been reduced after two decades of democracy, free-market economy and social policies to redress historical injustices. We go on to explore patterns of poverty and inequality as these pertain to different social groups, and seek to determine the persistence of racial and ethnic inequalities that so profoundly shaped the 
country's colonial era. We are also interested in exploring the extent to which Namibia's high level of inequality has impeded its progress in reducing poverty levels and whether the country is on track to meet the global Millennium Development Goal (MDG) of cutting poverty by half by 2015 .

The next section of the paper explores the challenges of comparing survey data on household consumption expenditure and presents the methodology for establishing comparability between the two datasets. We then go on to compare changes in poverty and inequality using a stochastic dominance framework and decomposition techniques. Finally, we conclude with a discussion of the policy implications of our findings.

\section{DATA AND METHODOLOGY}

The analysis in this paper is based on data from two rounds of the NHIES conducted in 1993/1994 and 2003/2004 by the Central Bureau of Statistics (CBS). Both rounds were of national coverage using a stratified two-stage probability sample. To collect data on household consumption expenditure, a combination of recall questions for certain infrequent food and non-food items were used alongside diaries in which households recorded daily transactions. To even out seasonal effects, data were collected over a full 12-month cycle, and, to limit respondent fatigue, participating households were changed every four weeks.

Despite these similarities, the methodology applied in the 2003/2004 survey differed in important ways from the previous survey. First, the sample size was doubled, primarily to reduce standard errors of estimates and to allow for greater geographical disaggregation in response to growing political focus on addressing spatial inequality and region-specific poverty. Second, modern technology such as digital scanning was used to capture data. Third, the length of time a person was required to have stayed in the household prior to the survey to qualify as a member was expanded from one to two weeks out of the preceding four. Fourth, there was a change in the way infrequent non-food expenditures were collected. In the first survey, the number of transactions listed on the form administered by interviewers included seven commodities (such as a motor vehicle, furniture and appliances, household animals) and seven categories of fees and loans (such as school fees, repayment of loans). In the 2003/2004 survey, both the number and details of infrequent expenditures were increased, with an explicit aim to improve the capture of these expenditures.

According to the CBS (2006: page ii), because of these changes, it: "makes it difficult to separate the effects of change in methodology from actual development when the two surveys are compared. Therefore, as a general rule the reader is urged to treat observed changes between the two surveys as more indicative of direction rather than as precise estimates." (Emphasis in the original source.)

A direct comparison between the data from the two surveys shows that total monthly consumption expenditure among the poorest 10 per cent of households had increased by a factor of 4.5 and by a factor of 3.7 for the wealthiest 10 per cent. Food expenditure grew by a factor of 4.4 for the poorest 10 per cent of households compared to a factor of 2.5 for the wealthiest 10 per cent. This corresponds to an average annual growth rate of real household expenditure of 12-25 per cent over the period (highest for the poorest 10 per cent), which does appear extremely and unrealistically high, especially given a modest rate of growth in real GDP per capita over the period and the great degree of inequality with which the growth is distributed (CBS, 2008). ${ }^{2}$ 
Moreover, the changes in the levels of real household expenditure occur alongside a shift in the composition of expenditure (adjusted for inflation and household size and composition) as reflected in the non-parametric Engel curves in Figure 1. The share of food expenditure to total expenditure is higher in the most recent survey, especially among the poorest households; the food share of a large group of low-income households is visibly extremely low in $1993 / 1994$. This is probably an indication that food expenditure from own consumption was severely underestimated in the earlier survey, which was conducted at a time when food markets (especially for maize, which is the main staple) in rural areas were particularly underdeveloped and hence price information was scarce (Levine and Roberts, 2008).

FIGURE 1

\section{Non-parametric Engel Curves (Lowess regression)}
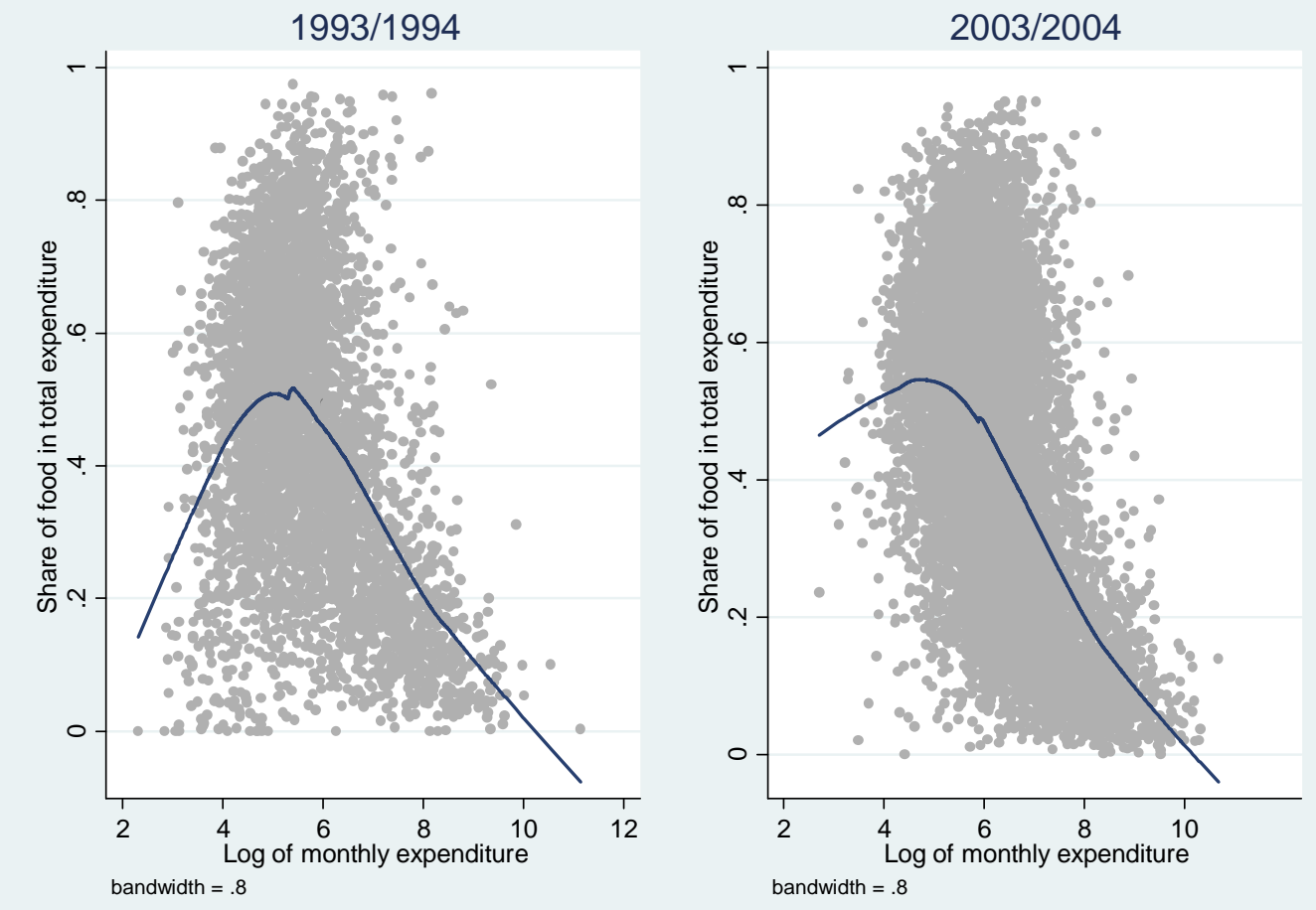

It is somewhat surprising that the more detailed analysis of non-food items has not generated a downward shift in the Engel curve in 2003/2004, but this could be offset by one or more of the other methodological issues that are likely to have biased the 1993/1994 data. All in all, the 1993/1994 survey seems to severely under-report household expenditure, especially related to food and especially among the poorest households, which, if not corrected, would tend to exaggerate the levels of poverty at the baseline and thus the degree of any poverty reduction that may have taken place between the two household surveys.

\subsection{ECONOMETRIC STRATEGY AND ESTIMATION}

To address the challenges of comparing the data on household consumption expenditure between the surveys, we rely on an extension of the micro-econometric modelling approach $t$ hat has been developed in relation to 'poverty mapping' (Elbers et al., 2003; Hentschel et al., 2000). 
The procedure typically entails matching household survey and census data to generate small-area estimates of poverty and inequality, and overcomes the common problem of limited or no income or expenditure data in censuses. The household survey is used to model the relationship between standard of living and a number of household characteristics, after which the relationship is applied to the same household attributes in the census data. There is a small but growing literature that extends this technique to survey-to-survey rather than survey-to-census imputations (for example, Minot, 2007; Kijima and Lanjouw, 2003). The inherent advantage of the method is that it can provide more frequent updates of poverty and inequality, as well as remedy comparability problems such as those between the two NHIES rounds. The methodology also bypasses the need for separate price adjustments, which is often a challenge in surveys of this type.

For the purposes of our study we first use multivariate analysis to establish the relationship between the common variables in the two rounds of the NHIES and the expenditure data in 2003/2004, and then we infer this relationship onto the 1993/1994 dataset to create a new consumption expenditure variable. In practice we estimate the following semilog regression, using the natural logarithm of per capita consumption expenditure $y$ for all households $h$ :

$$
\begin{aligned}
& \ln \left(y_{h, 03 / 04}\right)=\beta_{0}+\beta_{1}\left(D E M_{h, 03 / 04}\right)+\beta_{2}\left(E D U_{h, 03 / 04}\right)+ \\
& \beta_{3}\left(P A S_{h, 03 / 04}\right)+\beta_{4}\left(F E A_{h, 03 / 04}\right)+\beta_{5}\left(I N C_{h, 03 / 04}\right)+\xi_{h, 03 / 04}
\end{aligned}
$$

where $D E M$ is a series of demographic characteristics of the household, EDU a series of education variables for the head of household, PAS represents a series of physical assets owned by the household, FEA are physical household features, INC is the main source of income of the household, and $\xi$ is a normally distributed random error term. Estimators from Equation 1 are obtained using data from the later, more reliable survey and are then used to 'predict' consumption levels in 1993/1994, generating a distribution of values for $\hat{y}_{h, 93 / 94}$.

In selecting variables for inclusion it is critical that these are measured in the same way in the surveys that are being matched. We select variables that are standard in the analysis of poverty determinants, and since we are mainly interested in creating a strong model fit we do not worry about possible endogeneity effects (Minot, 2007; Christiaensen et al., 2008).

Fortunately, unlike the variables related to household expenditure, there were no major changes in the definition of the categorical variables which are used for this part of the analysis. Summary statistics for the variables are presented in Appendix Table, which indicate that between the two surveys there have been some improvements in the physical features of Namibian households and some asset accumulation. This is evidence of an improvement in welfare that we expect will contribute to a reduction in poverty over the period, although this fall is expected to be less than when using the unadjusted 1993/1994 data.

To effectively accommodate spatial differences, a number of stratum-level models of household welfare were estimated, beginning with zonal (urban and rural) disaggregation. ${ }^{3}$ 
Having determined the independent variables, we proceeded to estimate 24 separate models, corresponding to 13 rural (one for each of the 13 regions) and 11 urban (one for each region except Ohangwena and Omusati where there were no urban households in the 1993/1994 sample). ${ }^{4}$ OLS regression results are presented in Appendix Talbe.The resultant R-squared statistics are quite high, which gives confidence to the strength of the estimated models. The final step in our estimation process was to add a normally distributed error term to the fitted values, which we did using STATA's 'drawnorm' command with 2000 draws. On that basis we created an estimated value of monthly expenditure for each household in the 1993/1994 sample. ${ }^{5}$

\subsection{METHODOLOGICAL DISCUSSION}

Two issues related to the adopted estimation strategy in particular warrant further discussion. The first issue relates to why we did not simply seek to adjust directly for the relative underreporting of expenditure in the first survey. Other studies have adopted such an approach. For instance, when faced with difficulties in comparing expenditure items in three household surveys conducted in Zambia in the 1990s, McCulloch et al. (2000) 'reconstruct' the total expenditure variable for the surveys including only components and sub-components that are common in the survey instrument for all surveys and using the same reference period. Another example is Deaton (2003), who seeks to overcome changes in the recall period for certain expenditure items in the $50^{\text {th }}$ and $55^{\text {th }}$ rounds of the National Sample Survey in India by estimating poverty as a function of the expenditure component for which the recall period was unchanged between the surveys.

However, as explained above, in the case of the Namibian surveys it is clear that comparability issues go beyond just one segment of the questionnaire, covering a spate of methodological aspects, which make the target for adjustment less obvious. Moreover, a challenge with directly restoring comparability between estimated household consumption expenditure is the possibility of substitution between included and excluded expenditure sub-components, which in turn would contradict the Engel curve stability assumption.

The second methodological issue relates to the principal assumption associated with the small-area estimation methodology, which is that the modelled relationship between household consumption expenditure and the set of chosen household characteristics using the 2003/2004 NHIES data have remained constant since the 1993/1994 round of the survey. If regression coefficients are assumed to have remained unchanged, then changes in levels of expenditure that occurred over the period are ascribed to changes in the household characteristics.

Accordingly, any dynamics in poverty and inequality that are observed over the interval would be indicative of demographic change, asset accumulation or depletion, and changes in educational attainment and access to basic services. This stability assumption is generally argued on the grounds that model parameters reflect microeconomic relationships that are less likely to be affected by macro policies (Minot, 2007; Stifel and Christiaensen, 2006). There is no reason to believe that this may not be the case when it comes to the demographic and physical attribute variables included in the model.

However, for the educational attainment and income variables we were less sure. For instance, while there is evidence of steeply increasing returns to education in Namibia, it is less clear whether the gradient has changed after the opening up of the labour markets 
after the transition to majority rule and the acceleration of economic growth (World Bank, 2005). We, therefore, decided to run several versions of the model based on Equation 1. We were particularly interested in comparing results from the full specification of the model with an alternative specification where the EDU and INC variables were excluded.

Figure 2 presents kernel density curves for three distributions: the original 1993/1994 observed expenditure variable (adjusted for inflation using CPI data) and two predicted distributions, one based on estimates using all the variables and one based on estimates excluding EDU and INC. All three distributions have the standard log-normal shape but with some lumpiness on the right side-a reflection of a group of highly wealthy households in the distribution. The leftward shift of the two predicted distributions suggests that, in line with expectations, the survey matching methodology corrects for underestimation of the 1993/1994 household expenditure.

\section{FIGURE 2}

\section{Density Curves for 1993/1994 Household Expenditure}

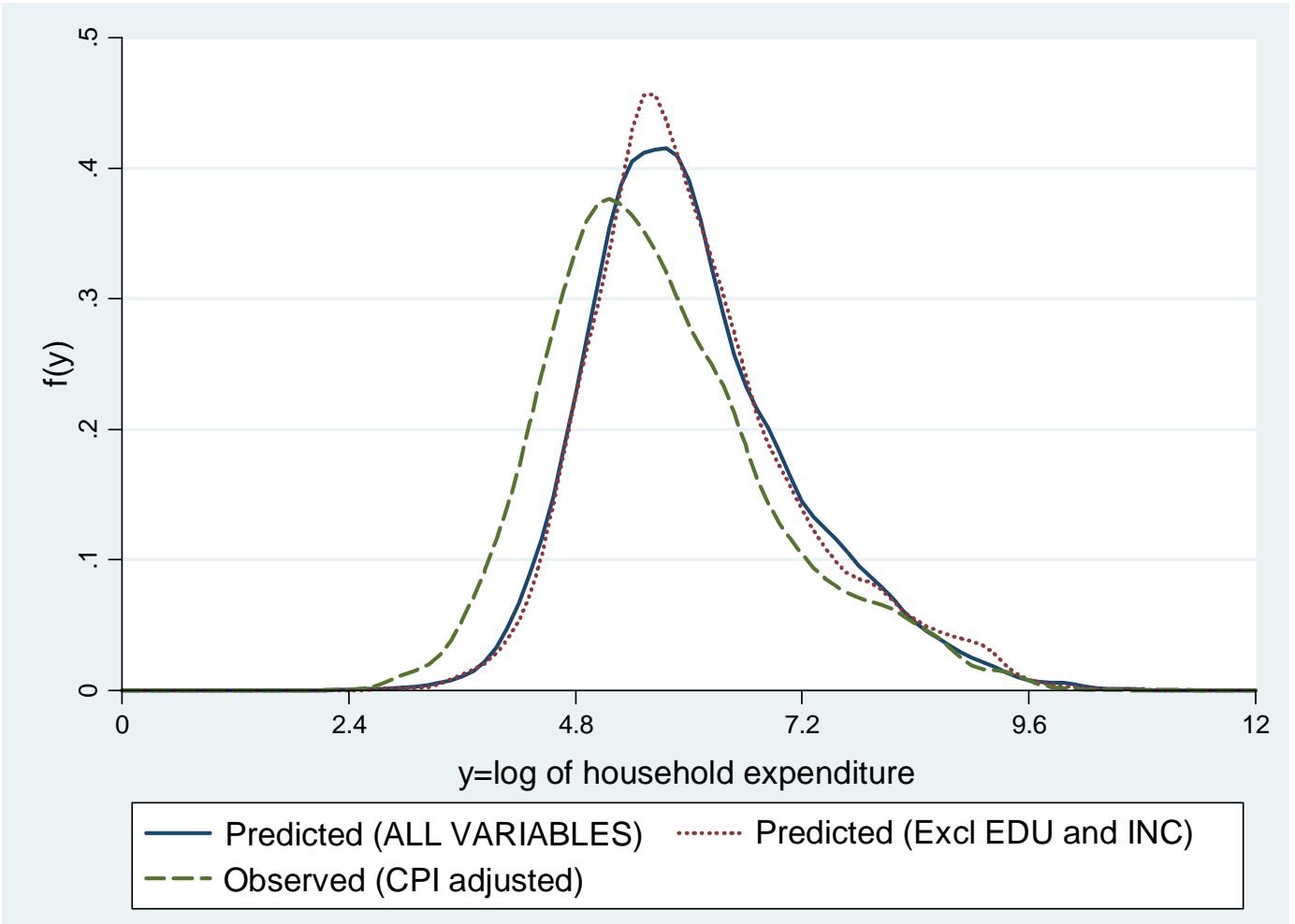

However, the two predicted distributions are quite close, indicating that the survey matching methodology is quite robust to differences in specification of the underlying model. This is in line with Christiaensen et al. (2008), who find that the predictive power of the smallarea estimation methodology in applications for Kenya, Russia and Vietnam is strongest when geographic indicators, physical features of the household and asset ownership are included. Including labour and education variables adds only limited value, which is encouraging given possible doubts about the stability of the returns to these assets in rapidly changing environments. 


\section{CHANGES IN POVERTY AND INEQUALITY}

In this section we present estimates of poverty and inequality for Namibia using the 2003/2004 survey data and the new predicted per capita consumption expenditure estimates for $1993 / 1994$. The welfare variables for both years were adjusted to take into account household size and composition using the adult equivalence scales set by the CBS. ${ }^{6}$ Robustness checks are conducted by comparing the observed $2003 / 2004$ results with both sets of predicted variables for 1993/1994 using the full model specification (all variables) and the alternative specification (excluding EDU and INC).

\subsection{MEASURING CHANGES IN POVERTY AND INEQUALITY}

Our assessment of changes in poverty and inequality follows Araar (2007) by formally testing the difference between welfare distributions in discrete data building on the theory of stochastic dominance (Atkinson, 1987; Foster and Shorrocks, 1988). In this framework, cumulative density functions, or 'FGT curves' derived from the Forster, Greer and Thorbecke (1984) class of poverty measures, $\Delta P(\alpha ; z)$, are used directly to test for poverty dominance. The poverty line is $z$, and $\alpha$ is the poverty aversion parameter, which takes the value of 0 in the case of the poverty headcount, a value of 1 in the case of the poverty gap and a value of 2 in the case of the squared poverty gap. Poverty in the 2003/2004 distribution dominates (i.e. has lower poverty than) the 1993/1994 distribution for the order $s=\alpha+1$ if:

$$
\Delta P(\alpha ; z)=P_{93 / 94}(\alpha ; z)-P_{03 / 04}(\alpha ; z)>0, \forall z \in[0 ; \infty]
$$

The FGT poverty measures are decomposable into $L$ mutually exclusive sub-groups, and total poverty is the sum of poverty in each sub-group weighted by $\varphi^{l}$, which is the relative share of the sub-group in the total population:

$$
P(\alpha ; z)=\sum_{l=1}^{L} \varphi^{l} P(l ; \alpha ; z)
$$

Inequality dominance is determined by comparing the difference between Lorenz curves. Inequality in the 1993/1994 distribution dominates the 2003/2004 distribution, in the second order (i.e. has lower inequality), if the Lorenz curve of 1993/1994 is everywhere above the Lorenz curve of 2003/2004, or:

$$
\Delta L(p)=L_{93 / 94}(p)-L_{03 / 04}(p)>0, \forall p \in[0 ; 1]
$$

where $p$ refers to the percentile in the distribution. We follow Datt and Ravallion (1992) in decomposing the change in the FGT measure into one component that represents growth $(G)$ or difference in the mean household expenditure, and one component that represents distributional changes or differences in the relative income shares $(D)$, plus a residual term $(r)$ : 


$$
\Delta P(\alpha ; z)=G+D+r
$$

The two first components can be represented by:

$$
\begin{aligned}
& G=\left[P_{93 / 94}\left(\alpha ; \frac{z \mu_{93 / 94}}{\mu_{03 / 04}}\right)-P_{93 / 94}(\alpha ; z)\right] \\
& D=\left[P_{03 / 04}\left(\alpha ; \frac{z \mu_{03 / 04}}{\mu_{93 / 94}}\right)-P_{93 / 94}(\alpha ; z)\right]
\end{aligned}
$$

where the first expression of $G$ is the poverty level in 1993/1994 after expenditure has been scaled by the difference in means to yield a distribution with a mean equal to 2003/2004 and inequality unchanged (Duclos and Araar, 2006). $G$ is thus the difference between the two distributions with the same relative income shares but with different mean incomes. The first expression of $D$ is poverty in 2003/2004 after expenditure for that year has been scaled to yield a distribution with a mean equal to $1993 / 1994$. $D$ is thus the difference between two distributions with identical mean incomes but with different inequality. The residual is present whenever a change in the poverty measure due to changes in the mean (or distribution) also depends on the precise distribution (or mean) (Datt and Ravallion, 1992). ${ }^{7}$

We also derive standard measures of inequality. The first is the Gini coefficient, which is computed as 1 minus twice the area under the Lorenz curve and ranges from 0 to 1 , with each extreme representing perfect equality and perfect inequality, respectively. The Gini coefficient is particularly useful for its intuitive appeal, the fact that it is a rather well-established indicator in the Namibian context, and is computed for a large number of countries, which facilitates some international comparison. Unlike the Gini coefficient, the generalised entropy class of inequality indices are perfectly decomposable into inequality between and inequality within different population groups (Cowell, 1995). ${ }^{8}$ For our investigation into the changes in inequality, and in particular our interest in the role of racial and ethnic and other social groups in driving inequality, we make use of the sub-group decomposability of the general entropy indices (I) whereby total inequality can be assessed fully as the sum of within-group and between-group inequality:

$$
I(\mathrm{y} ; \theta)=\sum_{l=1}^{L} \varphi^{l}\left(\frac{\mu^{l}}{\mu}\right) I\left(\mathrm{y}^{l} ; \theta\right)+I\left(\mu^{1}, \ldots, \mu^{l}, \ldots, \mu^{L} ; \theta\right)
$$

Here $\mu$ is the mean household expenditure, and $\theta$ represents the weight given to household expenditure at different parts of the distribution; at low values of $\theta$ the inequality index is more sensitive to changes at the lower end of the distribution. The first part of Equation 8 on the right side represents within-group inequality, $I_{W}(\theta)$, and the second part the between-group component of inequality, $I_{B}(\theta)$. Within-group inequality is a weighted average of inequality within sub-groups. Between-group inequality can be interpreted as the amount of inequality that would prevail if everyone had the average expenditure of their 
group. In our presentation of results we focus on three special cases that reflect variation in $\theta$; when $\theta=0, I$ is the mean $\log$ deviation, when $\theta=1, I$ is the Theil index, and when $\theta=2, I$ is half the squared coefficient of variation.

Denoting a social-group partition of the population by $\Pi$, relative between-group inequality for that group, $R I_{B}(\theta ; \Pi)$, can be expressed as:

$$
R I_{B}(\theta ; \Pi)=\frac{I_{B}(\theta ; \Pi)}{I(\theta)}
$$

However, as suggested by Elbers et al. (2008) relative between-group inequality should ideally be represented as a share of the maximum between-group inequality, rather than as a share of total inequality. In this approach total inequality is replaced in the denominator of Equation 9 with the maximum between-group inequality that could be obtained if the number of groups and their sizes were restricted to be the same as for the numerator. The result is a measure of between-group inequality, which we will refer to as $\widehat{R I}_{B}(\theta ; \Pi)$, that is normalised by the number of groups under examination and their relative sizes. This enables us to conduct direct comparisons of between-group inequality between the social groups in Namibia, which have different numbers of social partitions, and to make comparisons over time, taking into account changes in population sub-group shares. The normalised measure of between-group inequality also facilitates a more ready comparison with other countries. ${ }^{9}$

\subsection{EMPIRICAL RESULTS FOR CHANGES IN POVERTY}

The first set of empirical results is for the measures of poverty using the FGT class of poverty indices. As the value for $z$, we use the upper-bound poverty line for Namibia whereby households that have total consumption expenditure per capita of less than N\$262 per month are classified as 'poor' (CBS, 2008). Households are weighted by population size, so poverty measures can be expressed with reference to individuals, and poverty estimates are weighted using the sampling weights from the survey. Standard errors are computed in STATA using information about the survey structure. ${ }^{10}$ Disaggregated results are presented in Table 1. A primary finding from our analysis is that the incidence of poverty fell between the two periods under study from 49 per cent to 38 per cent of the population; a change that is statistically significant at the 99 per cent confidence level. This reduction in poverty is in line with expectations given the improvements in educational attainment, physical assets of the household and other variables used in the survey matching. 
TABLE 1

Poverty Measures for Namibia

\begin{tabular}{|c|c|c|c|c|c|c|c|c|c|}
\hline & \multicolumn{3}{|c|}{$\begin{array}{l}\text { Predicted 1993/1994 } \\
\text { (ALL VARIABLES) }\end{array}$} & \multicolumn{3}{|c|}{ Observed 2003/2004 } & \multicolumn{3}{|c|}{ Change } \\
\hline & $P(\alpha=0)$ & $P(\alpha=1)$ & $P(\alpha=2)$ & $P(\alpha=0)$ & $P(\alpha=1)$ & $P(\alpha=2)$ & $P(\alpha=0)$ & $P(\alpha=1)$ & $P(\alpha=2)$ \\
\hline Namibia & 0.486 & 0.196 & 0.103 & 0.377 & 0.128 & 0.060 & $\begin{array}{c}- \\
0.109 * * * \\
\end{array}$ & $\begin{array}{c}- \\
0.068 * * * \\
\end{array}$ & $-0.043 * * *$ \\
\hline \multicolumn{10}{|c|}{ Sex of head of household } \\
\hline Female & 0.550 & 0.230 & 0.123 & 0.403 & 0.137 & 0.064 & $\begin{array}{c}- \\
0.147^{* * *}\end{array}$ & $\begin{array}{c}- \\
0.093^{* * *}\end{array}$ & $-0.059 * * *$ \\
\hline Male & 0.446 & 0.175 & 0.091 & 0.359 & 0.122 & 0.058 & $\begin{array}{c}- \\
0.087^{* * *}\end{array}$ & $\begin{array}{c}- \\
0.053^{* * *}\end{array}$ & $-0.033 * * *$ \\
\hline \multicolumn{10}{|l|}{ Zone } \\
\hline Urban & 0.256 & 0.100 & 0.053 & 0.170 & 0.059 & 0.029 & $\begin{array}{c}- \\
0.086^{* * *}\end{array}$ & $\begin{array}{c}- \\
0.041^{* * *}\end{array}$ & $-0.023 * *$ \\
\hline Rural & 0.578 & 0.235 & 0.124 & 0.487 & 0.164 & 0.077 & $\begin{array}{c}- \\
0.091 * * *\end{array}$ & $\begin{array}{c}- \\
0.070^{* * *}\end{array}$ & $-0.047 * * *$ \\
\hline \multicolumn{10}{|l|}{ Region } \\
\hline Caprivi & 0.509 & 0.201 & 0.105 & 0.365 & 0.119 & 0.054 & $-0.144 * *$ & $-0.082 * *$ & $-0.051 * *$ \\
\hline Erongo & 0.331 & 0.151 & 0.090 & 0.143 & 0.050 & 0.024 & $\begin{array}{c}- \\
0.188^{* * *} \\
\end{array}$ & $\begin{array}{c}- \\
0.101^{* * *} \\
\end{array}$ & $-0.066 * *$ \\
\hline Hardap & 0.406 & 0.169 & 0.090 & 0.420 & 0.180 & 0.097 & 0.013 & 0.011 & 0.007 \\
\hline Karas & 0.405 & 0.222 & 0.142 & 0.327 & 0.133 & 0.072 & -0.078 & -0.089 & -0.070 \\
\hline Kavango & 0.614 & 0.259 & 0.142 & 0.641 & 0.275 & 0.150 & 0.027 & 0.016 & 0.008 \\
\hline Khomas & 0.115 & 0.36 & 0.016 & 0.081 & 0.021 & 0.008 & -0.033 & $-0.015^{*}$ & $-0.070 * *$ \\
\hline Kunene & 0.479 & 0.175 & 0.88 & 0.368 & 0.148 & 0.076 & -0.112 & -0.027 & -0.012 \\
\hline Ohangwena & 0.670 & 0.263 & 0.129 & 0.554 & 0.164 & 0.065 & $-0.116 * *$ & $\begin{array}{c}- \\
0.098 * * *\end{array}$ & $-0.063 * * *$ \\
\hline Omaheke & 0.568 & 0.290 & 0.189 & 0.414 & 0.162 & 0.085 & $-0.154 * *$ & $\begin{array}{c}- \\
0.0128 * *\end{array}$ & $-0.104 * *$ \\
\hline Omusati & 0.517 & 0.190 & 0.093 & 0.384 & 0.103 & 0.043 & $\begin{array}{c}- \\
0.133^{* * *} \\
\end{array}$ & $\begin{array}{c}- \\
0.087 * * * \\
\end{array}$ & $-0.050 * * *$ \\
\hline Oshana & 0.482 & 0.186 & 0.090 & 0.257 & 0.070 & 0.027 & $\begin{array}{c}- \\
0.225^{* * *} \\
\end{array}$ & $\begin{array}{c}- \\
0.116^{* * *} \\
\end{array}$ & $-0.063 * * *$ \\
\hline Oshikoto & 0.642 & 0.242 & 0.122 & 0.490 & 0.142 & 0.059 & $\begin{array}{c}- \\
0.152^{* * *}\end{array}$ & $\begin{array}{c}- \\
0.100 * * * \\
\end{array}$ & $-0.064 * * *$ \\
\hline Otjozondjupa & 0.479 & 0.215 & 0.126 & 0.390 & 0.153 & 0.079 & -0.090 & -0.062 & -0.047 \\
\hline \multicolumn{10}{|c|}{ Education of head of household } \\
\hline No formal & 0.663 & 0.281 & 0.153 & 0.611 & 0.223 & 0.110 & $-0.053^{* *}$ & $\begin{array}{c}- \\
0.057 * * *\end{array}$ & $-0.043 * * *$ \\
\hline Primary & 0.546 & 0.223 & 0.117 & 0.445 & 0.147 & 0.068 & $\begin{array}{c}- \\
0.100 * * * \\
\end{array}$ & $\begin{array}{c}- \\
0.075 * * * \\
\end{array}$ & $-0.049 * * *$ \\
\hline Secondary & 0.274 & 0.096 & 0.045 & 0.186 & 0.054 & 0.022 & $0.089 * * *$ & $\begin{array}{c}- \\
0.042^{* * *} \\
\end{array}$ & $-0.023 * * *$ \\
\hline Tertiary & 0.065 & 0.011 & 0.002 & 0.017 & 0.004 & 0.001 & -0.048 & -0.008 & -0.001 \\
\hline \multicolumn{10}{|c|}{ Main source of income } \\
\hline Non-farm business & 0.386 & 0.143 & 0.071 & 0.321 & 0.116 & 0.056 & -0.064 & -0.026 & -0.015 \\
\hline Pension & 0.670 & 0.314 & 0.188 & 0.660 & 0.251 & 0.125 & -0.010 & $-0.063 * *$ & $-0.064 * *$ \\
\hline $\begin{array}{l}\text { Subsistence } \\
\text { farming }\end{array}$ & 0.604 & 0.239 & 0.121 & 0.483 & 0.146 & 0.063 & $\begin{array}{c}- \\
0.121^{* * *}\end{array}$ & $\begin{array}{c}- \\
0.093^{* * *}\end{array}$ & $-0.058 * * *$ \\
\hline Salary and wages & 0.299 & 0.116 & 0.061 & 0.195 & 0.065 & 0.031 & $\begin{array}{c}- \\
0.104 * * *\end{array}$ & $\begin{array}{c}- \\
0.051^{* * *}\end{array}$ & $-0.029 * * *$ \\
\hline
\end{tabular}




\begin{tabular}{|c|c|c|c|c|c|c|c|c|c|}
\hline \multicolumn{10}{|c|}{ Main language spoken } \\
\hline Afrikaans & 0.116 & 0.048 & 0.026 & 0.111 & 0.035 & 0.017 & -0.006 & -0.013 & -0.009 \\
\hline Caprivi & 0.527 & 0.215 & 0.121 & 0.318 & 0.102 & 0.046 & $\begin{array}{c}- \\
0.209 * * *\end{array}$ & $\begin{array}{c}- \\
0.113^{* * *}\end{array}$ & $-0.075 * * *$ \\
\hline English & 0.000 & 0.000 & 0.000 & 0.007 & 0.003 & 0.001 & 0.007 & 0.003 & 0.001 \\
\hline German & 0.000 & 0.000 & 0.000 & 0.000 & 0.000 & 0.000 & 0.000 & 0.000 & 0.000 \\
\hline Herero & 0.445 & 0.184 & 0.105 & 0.244 & 0.086 & 0.041 & $\begin{array}{c}- \\
0.201^{* * *}\end{array}$ & $\begin{array}{c}- \\
0.099 * * *\end{array}$ & $-0.064 * * *$ \\
\hline Nama/Damara & 0.540 & 0.257 & 0.154 & 0.448 & 0.194 & 0.105 & $-0.092 * *$ & $-0.063 * *$ & $-0.049 * *$ \\
\hline Oshiwambo & 0.541 & 0.207 & 0.102 & 0.379 & 0.106 & 0.043 & $\begin{array}{c}- \\
0.162^{* * *}\end{array}$ & $-0.100 * *$ & $-0.059 * * *$ \\
\hline Rukavango & 0.589 & 0.250 & 0.136 & 0.635 & 0.269 & 0.145 & 0.046 & 0.019 & 0.009 \\
\hline Khoisan & 0.736 & 0.287 & 0.173 & 0.716 & 0.322 & 0.181 & -0.020 & 0.035 & 0.008 \\
\hline Setswana & 0.167 & 0.099 & 0.071 & 0.177 & 0.030 & 0.006 & 0.010 & -0.069 & -0.065 \\
\hline
\end{tabular}

Note: * indicates that the change is significantly different at the 90 per cent level,

** at the 95 per cent level, and *** at the 99 per cent level.

We find that poverty incidence is slightly higher among individuals living in households that are headed by females ( 40 per cent) compared to male-headed households ( 36 per cent), although the difference is not statistically significant. Moreover, the difference has narrowed since the earlier survey. ${ }^{11}$ Poverty incidence is almost three times higher in rural areas (49 per cent) than in urban areas ( 17 per cent) and has fallen by 9 percentage points in both rural and urban areas. In relative terms, however, poverty incidence has fallen by 34 per cent in urban areas and 16 per cent in rural areas.

There are also discernible differences according to other variables, such as region, language group and education. Among the country's administrative regions, Kavango, Omaheke and Oshikoto have the highest levels of poverty, at 64 per cent, 55 per cent and 49 per cent, respectively. By contrast, in the more urbanised regions of Khomas and Erongo poverty incidence is 8 per cent and 14 per cent, respectively. Moreover, the change in poverty levels between the two surveys appears very uneven, with some regions seeing large reductions in the incidence of poverty-especially Oshana and Erongo, where the fall was close to 20 percentage points - compared to other regions such as Hardap and Kavango, where poverty incidence actually went up (although not to a statistically significant degree).

The differences in poverty incidence are also striking among individuals living in households where the main language is Khoisan (73 per cent) and Rukavango (64 per cent) on the one hand, and in households where the main language is English (1 per cent) and German (0) on the other hand. Among households where Caprivi, Herero, Oshiwambo and Nama/Damara languages are mainly spoken the incidence of poverty has fallen significantly. Since most of the other language groups are quite small in size, estimates of change come with large standard errors; therefore, the changes are not found to be statistically significant.

All in all, these results point to pockets of deep and persistent poverty in Namibia rooted in geographic, linguistic and perhaps ethnic and racial differences that trace back to preIndependence. Unfortunately, we are not able to discern racial differences directly, as the CBS does not have race as a background variable in the NHIES. ${ }^{12}$ 
As expected, there is a strong inverse relationship between the level of education of the head of the household and the incidence of poverty. Poverty levels remain highest among individuals in households where the head has no formal education (61 per cent) or only primary education (45 per cent). Among households where the head has completed secondary education the incidence of poverty is much lower (19 per cent), and among those who have completed tertiary education, poverty is almost non-existent ( 2 per cent).

There has been a significant move out of subsistence agriculture since 1993/1994, and the results show that levels of poverty have also fallen among individuals in these households. Still, nearly half (48 per cent) of those individuals residing in households dependent on subsistence farming live in poverty. Poverty incidence has also fallen significantly in households where the main source of income is wages and salaries, which is an indication of the importance of creating employment to spur poverty reduction. Still, 20 per cent of the population living in households where salary and wages are the main source of income are poor. In other words, a salaried income is by no means a guarantee of a life above the poverty line in Namibia.

We find falling values of both the poverty gap and the squared poverty gap for Namibia as a whole, in both male- and female-headed households and in both urban and rural areas. This is an indication of improvements in the welfare of the poorest households. However, when it comes to the two language groups most affected by poverty, Khoisan- and Rukavango-speakers, we find no statistically significant improvements. It is particularly noteworthy that while incidence of poverty has fallen roughly the same in urban and rural areas, the poverty gap has fallen much more in rural areas. This means that while poor people in rural areas have seen increased welfare, it has not been enough to lift them out of poverty to the same extent as among poor people in urban areas.

Part of the explanation is the larger initial poverty gap among rural households, which requires relatively larger welfare increases to move them out of poverty. However, these results also suggest that national policies for poverty reduction such as those seeking to expand salaried jobs, increase provision of basic services and provide cash transfers to vulnerable groups have had some effect, especially in urban areas where the physical and administrative infrastructure is more effective.

Using the stochastic dominance framework outlined above, we test the sensitivity of our results to the specification of our predicted welfare variables. In Figure 3 the difference in FGT estimates are plotted as per Equation 2 above for $\Delta P(0 ; z)$ and marked by 95 per cent confidence intervals in the shaded areas. The graphs are plotted using both predicted estimates for the 1993/1994 distribution. It is clear that within a large band of the value for the poverty line the change in poverty incidence between the two surveys is negative to a statistically significant degree, and that this holds for both 1993/1994 distributions.

On this basis it is possible to conclude that for all values of a poverty is lower in 2003/2004, and that this result is robust to our choice of poverty line and the specification of the predicted 1993/1994 variable. 
FIGURE 3

Estimated Difference Between FGT Curves for $P(\alpha=0)$ in $1993 / 1994$ and $2003 / 2004$
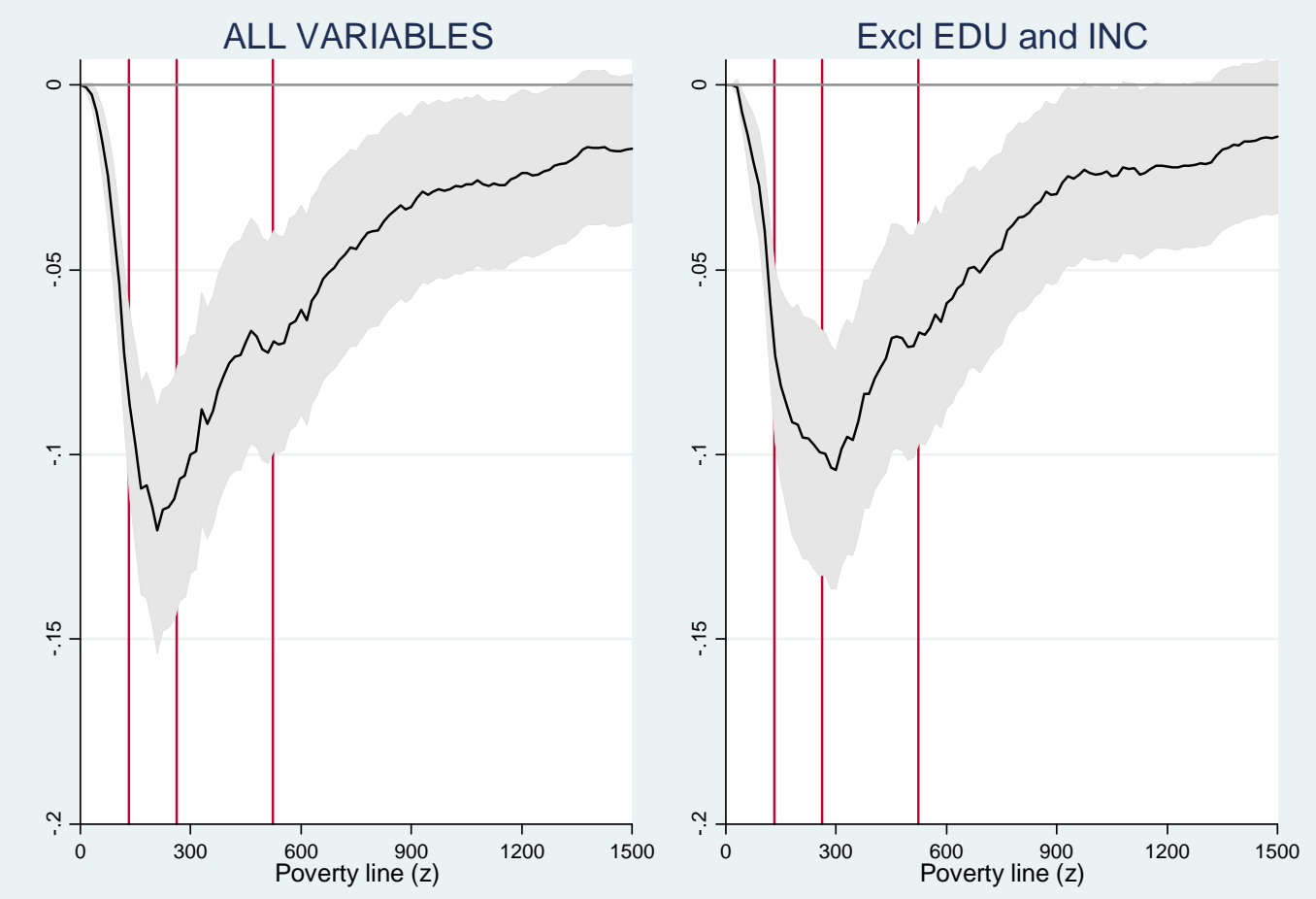

Note: Vertical lines are set at half, full and double value of the Namibian poverty line of $N \$ 262$. Shaded area represents 95 per cent confidence interval of the estimated difference between FGT curves.

So is Namibia on track to meet the MDG target of cutting poverty in half by 2015 ? The country very well could be. Assuming the same rate of progress in the years before $1993 / 1994$ as in the years to 2003/2004 implies a poverty incidence of 52 per cent in $1990 / 1991$, which could be considered as the baseline year for the MDG, with an associated target of 26 per cent in 2015. A linear extrapolation forward assuming a continuation of the rate of poverty reduction experienced between the two surveys implies a poverty level of exactly that target level in 2014/2015.

\subsection{EMPIRICAL RESULTS FOR CHANGES IN INEQUALITY}

Next we explore whether changes in poverty in Namibia have been accompanied by corresponding robust changes in inequality. We begin by exploring the Lorenz curves of the different welfare distributions using the stochastic dominance framework to assess changes over time. Figure 4 displays the differences between the Lorenz curves, $\Delta L(p)$, using Equation 4. It shows that the observed 2003/2004 distribution dominates both of the predicted 1993/1994 measures. However, since the confidence intervals overlap the null line at the full range of the distribution, this inequality dominance is not statistically significant. In other words, while the most recent welfare distribution dominates the predicted ones, thus indicating a reduction in inequality between the two surveys, the registered change in inequality is too small to be significant. This conclusion holds for both predicted welfare variables. 
FIGURE4

Difference Between Lorenz Curves in 1993/1994 and 2003/2004
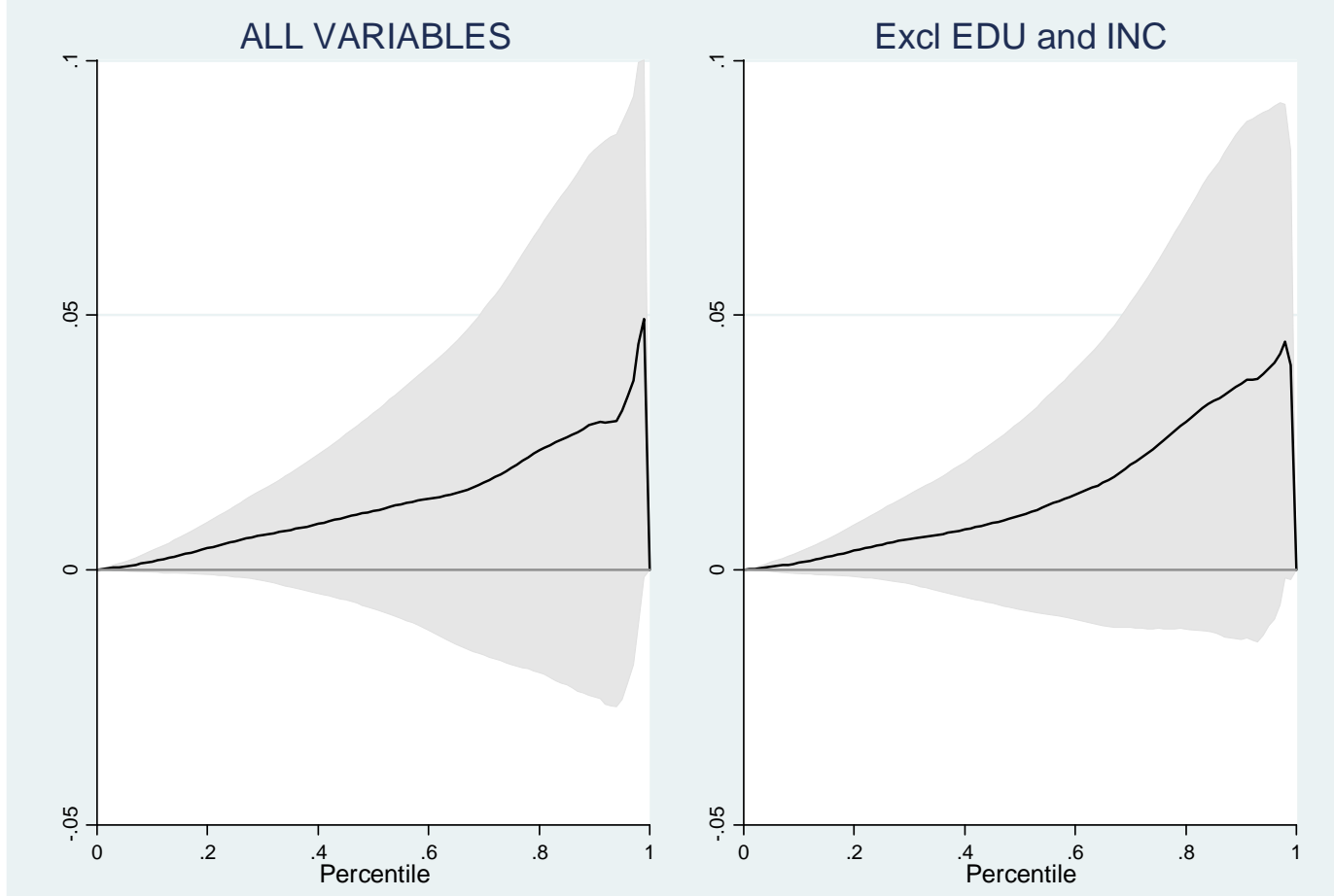

Note: Shaded area represents 95 per cent confidence interval of the estimated difference between Lorenz curves.

Table 2 presents the results on inequality for Namibia and for urban and rural areas for the two surveys. ${ }^{13}$ The results show that inequality fell slightly between the two surveys but also that, as expected from the analysis of the Lorenz curves, the changes are too small to be significant at conventional levels of confidence. The overall value of the Gini coefficient fell from 0.628 to 0.600 . This finding contrasts with the earlier official analysis of the two NHIES, which reported a Gini coefficient of 0.701 based on the 1992/1993 data (CBS, 1996) and 0.63 using the 2003/2004 data (CBS, 2008).

However, these earlier estimates of the Gini coefficient were reported for households, and so part of the change in the estimates presented in this paper is due to the reporting of Gini coefficient for individuals. We find that the Gini coefficient was 0.650 for households in $1993 / 1994$ and 0.629 in 2003/2004. Still, a key effect of applying the survey matching technique to the data has been to reduce the official estimate of inequality at the baseline. This is not surprising since the main effect of the adjustment was to raise welfare at the lower end of the distribution. Our results show that the Gini coefficient is higher for urban (0.574) than for rural areas (0.502), which we explain by a more uniformly lower distribution of incomes in rural areas reflected in the much higher poverty incidence there.

Table 2 also includes results for the three generalised entropy measures. These results point in the same direction as the Gini coefficient, namely towards small but insignificant decreases in inequality between the two surveys. This consistency among the indices is reassuring for the robustness of our conclusions. Note that when using the Gini coefficient and $I(\theta=0)$, inequality appears higher in urban areas than in rural areas. However, as the weight 
shifts towards sensitivity to inequality at the higher end of the income distribution, the inequality measure $I(\theta=2)$ becomes much higher for rural areas, indicating a higher level of inequality among the wealthy households there. This probably reflects pockets of extreme wealth concentrated around a limited number of commercial farms and mining operations in rural areas.

TABLE 2

Measures of Inequality in Namibia

\begin{tabular}{|c|c|c|c|c|c|}
\hline \multirow{4}{*}{ Gini } & \multirow[b]{2}{*}{ Namibia } & \multicolumn{2}{|c|}{$\begin{array}{l}\text { Predicted 1993/1994 } \\
\text { (ALL VARIABLES) }\end{array}$} & \multicolumn{2}{|c|}{ Observed 2003/2004 } \\
\hline & & 0.628 & $(0.589-0.666)$ & 0.600 & $(0.578-0.623)$ \\
\hline & Urban & 0.600 & $(0.560-0.640)$ & 0.574 & (0.548-0.599) \\
\hline & Rural & 0.550 & $(0.469-0.632)$ & 0.502 & $(0.476-0.529)$ \\
\hline \multirow[t]{3}{*}{$I(\theta=0)$} & Namibia & 0.708 & $(0.608-0.809)$ & 0.635 & $(0.579-0.691)$ \\
\hline & Urban & 0.692 & $(0.583-0.802)$ & 0.606 & $(0.543-0.670)$ \\
\hline & Rural & 0.536 & $(0.364-0.709)$ & 0.438 & $(0.390-0.487)$ \\
\hline \multirow[t]{3}{*}{$I(\theta=1)$} & Namibia & 0.922 & (0.748-1.096) & 0.777 & $(0.714-0.840)$ \\
\hline & Urban & 0.697 & $(0.573-0.820)$ & 0.613 & $(0.555-0.670)$ \\
\hline & Rural & 0.889 & $(0.482-1.296)$ & 0.673 & $(0.580-0.765)$ \\
\hline \multirow[t]{3}{*}{$I(\theta=2)$} & Namibia & 3.110 & $(1.907-4.312)$ & 1.852 & $(1.661-2.044)$ \\
\hline & Urban & 1.452 & $(0.898-2.006)$ & 1.022 & (0.896--1.148) \\
\hline & Rural & 4.967 & $(1.431-8.502)$ & 2.605 & $(2.038-3.172)$ \\
\hline
\end{tabular}

Note: 95 per cent confidence intervals in brackets.

\subsection{POVERTY DECOMPOSITION}

Table 3 lists the growth $(G)$, distribution $(D)$ and residual $(r)$ components of the change in the poverty headcount between the two NHIES rounds. For Namibia as a whole, out of the total reduction in the poverty headcount of 11 percentage points, 7 percentage points or 67 per cent was attributable to distribution-neutral growth in mean expenditure. Around 25 per cent was a result of changes in the income distribution. The small balance was captured in the residual. In other words, poverty reduction in Namibia in the post-Independence period has been driven by growth in household monetary welfare with smaller effects from changes in the welfare distribution. Similar conclusions hold for the other poverty measures. These results suggest that it has been possible to significantly reduce poverty in Namibia through income growth and despite only small reductions in inequality. It also points to the potential for further reductions in poverty using more inclusive and pro-poor policies, an issue discussed further below.

TABLE 3

Decomposition of Change in Poverty

\begin{tabular}{|l|c|c|c|c|c|c|c|}
\hline & $\Delta P(\alpha)$ & $G$ & $D$ & $r$ & $G / \Delta P(\alpha)$ & $D / \Delta P(\alpha)$ & $r / \Delta P(\alpha)$ \\
\hline$P(\alpha=0)$ & -10.9 & -7.3 & -2.7 & -0.9 & 66.6 & 24.9 & 8.5 \\
\hline$P(\alpha=1)$ & -6.8 & -4.3 & -2.6 & 0.1 & 63.0 & 38.8 & -1.8 \\
\hline$P(\alpha=2)$ & -4.3 & -2.6 & -1.9 & 0.2 & 61.0 & 44.8 & -5.7 \\
\hline
\end{tabular}




\subsection{EXPLORING BETWEEN-GROUP INEQUALITY}

We now look closer at the structure of inequality in Namibia through a decomposition of the generalised entropy indices for the two rounds of the NHIES. We use partitions by six different social groups common to both surveys: sex and highest level of education of head of household; location in terms of rural/urban zone and administrative region; main language spoken in the household; and its main source of income.

Table 4 presents the results for the decomposition of the two generalised entropy measures reporting the regular and normalised measures of relative between-group inequality as discussed above. As expected, the share of between-group inequality is higher when normalised by the number and relative size of the partitions, and the effect is particularly large for social groups with fewer sub-group partitions, notably zone and sex of head of household. However, the sex of the head of households appears to play only a minor part in overall inequality (although that does not mean that gender inequality is not a social concern; just that the household survey format does not pick that up directly). More than one third of total inequality can be explained by inequality between urban and rural zones when using the normalised measure, which is higher than when using the conventional approach to measuring between-group inequality.

TABLE 4

Relative Contribution of Between-group Inequality for $I(\theta=0)$

\begin{tabular}{|l|c|c|c|c|c|}
\hline Social group (I) & $\begin{array}{c}\text { Sub-group partitions } \\
\text { (L) }\end{array}$ & \multicolumn{2}{c|}{$\begin{array}{c}\text { Predicted 1993/1994 } \\
\text { (ALL VARIABLE) }\end{array}$} & \multicolumn{2}{c|}{ Observed 2003/2004 } \\
\hline & & $R I_{B}(\theta ; L)$ & $\widehat{R I}_{B}(\theta ; L)$ & $R I_{B}(\theta ; L)$ & $\widehat{R I}_{B}(\theta ; L)$ \\
\hline Zone & 2 & 0.180 & 0.260 & 0.223 & 0.332 \\
\hline Region & 13 & 0.301 & 0.320 & 0.308 & 0.323 \\
\hline Sex of head of household & 2 & 0.066 & 0.135 & 0.038 & 0.073 \\
\hline $\begin{array}{l}\text { Highest level of education of head of } \\
\text { household }\end{array}$ & 4 & 0.401 & 0.450 & 0.466 & 0.505 \\
\hline Main language spoken in the household & 11 & 0.409 & 0.468 & 0.349 & 0.367 \\
\hline Main source of income & 5 & 0.278 & 0.342 & 0.276 & 0.372 \\
\hline
\end{tabular}

When it comes to changes over time, three results are particularly noteworthy. First, the share of overall inequality for $I(\theta=0)$ that is explained by inequality between different language groups has fallen from 47 per cent in 1993/1994 to 37 per cent in 2003/2004. Second, the share of overall inequality that can be explained by inequality between partitions by the level of education of the head of household has increased from 45 per cent to 51 per cent between the two surveys. For partition by the main source of income of the household there has also been an increase in the contribution of between-group inequality, whereas for the other partitions the changes are smaller. These results are broadly the same when using $I(\theta=1)$, as indicated in Table 5 (and for $I(\theta=2)$ though not shown). It is also notable that while between-group inequality by regions has not changed over the decade between the two surveys, the degree of between-group inequality between urban and rural areas has increased. This is further evidence of the lingering effects of the geographical segregation of communities that underpinned Apartheid policies even as the democratic government has sought to focus on rural development and decentralisation. 
TABLE 5

Relative Contribution of Between-group Inequality for $I(\theta=1)$

\begin{tabular}{|l|c|c|c|c|c|}
\hline Social group (I) & $\begin{array}{c}\text { Sub-group partitions } \\
\text { (L) }\end{array}$ & \multicolumn{2}{c|}{$\begin{array}{c}\text { Predicted 1993/1994 } \\
\text { (ALL VARIABLS) }\end{array}$} & \multicolumn{2}{c|}{ Observed 2003/2004 } \\
\hline & & $R I_{B}(\theta ; L)$ & $\widehat{R I}_{B}(\theta ; L)$ & $R I_{B}(\theta ; L)$ & $\widehat{R I}_{B}(\theta ; L)$ \\
\hline Zone & 2 & 0.148 & 0.288 & 0.185 & 0.370 \\
\hline Region & 13 & 0.249 & 0.326 & 0.267 & 0.348 \\
\hline Sex of head of household & 2 & 0.047 & 0.180 & 0.030 & 0.097 \\
\hline $\begin{array}{l}\text { Highest level of education of head of } \\
\text { household }\end{array}$ & 4 & 0.345 & 0.423 & 0.431 & 0.508 \\
\hline Main language spoken in the household & 11 & 0.435 & 0.395 & 0.387 & 0.418 \\
\hline Main source of income & 5 & 0.202 & 0.266 & 0.230 & 0.394 \\
\hline
\end{tabular}

\subsection{DISCUSSION OF RESULTS}

A key implication of these results is that inequality in Namibia may be increasingly driven by differences in levels of education and less by differences related to linguistic group, which is sometimes used as a proxy for ethnicity and race (CBS, 2008). It is particularly striking that by partitioning the population according to just four sub-groups of educational attainment we are able to explain half of total inequality in Namibia. This is testament to the historical backlog in providing education to the majority of the population resulting from the bantu system of education and the challenges that persist in redressing its perverse outcomes more than a decade after the formal end of Apartheid in Namibia. According to the World Bank (2005), in 2001 only 41 per cent of students from the northern regions attained the minimum score required for entry into senior secondary school, compared to 63 per cent in the rest of the country. Moreover, using data from the 2001 census, Levine (2007) shows that rates of literacy and gross enrolment rates for primary, secondary and tertiary education for language groups Otjiherero, Nama/Damara and, especially, San have remained substantially lower than the national average.

Given the estimation methodology for the baseline welfare distribution, the growing contribution to overall inequality from inequality between different educational groups can be attributed to increased provision and uptake of, especially, secondary and tertiary education in the post-Apartheid period. It is somewhat counter-intuitive that this expansion in education, generally regarded as an essential element in a pro-poor strategy and central to the strategy of national reconciliation, may have effects that are increasing inequality.

However, this 'paradox of progress' is consistent with findings from elsewhere (for example, Bourguignon et al., 2005). The effect of increasing inequality is attributable to convexities in the returns to education, which imply that the marginal benefit from an increase in the level of education is higher for more-educated people than for the less-educated. This is very much the situation in Namibia. As reported by the World Bank (2005), returns to primary and to junior secondary education are extremely low-in fact, negative for primary education-and statistically insignificant. The returns to senior secondary education and post-secondary education, on the other hand, are higher than for most other countries in sub-Saharan Africa. 
Even if between-group inequality for the language groups has fallen since Independence, it is clear that the legacy of Apartheid and its racial divide endures. The estimate of normalised between-group inequality for language in Namibia is almost identical to the estimate of 37 per cent that Elbers et al. (2008) present for South Africa using 20 racial and language group categories. However, that study also showed that when using a purely racial divide, dividing the population into 'whites' and 'non-whites', the importance of between-group inequality more than doubles. This suggests that using language groups as a proxy for race may severely underestimate between-group inequality and that, to get a truer picture of the racial divide in Namibia, the CBS needs to revise its survey instrument to record more directly the racial background of respondents.

Since linguistic group may not be the best proxy for race and degree of historical disadvantage, we cannot attribute the falling contribution of inequality between linguistic groups to improvements generated by policies of affirmative action towards 'historically disadvantaged groups', which have guided government policies in the post-Independence period in areas such as employment, access to capital and land ownership. Another reason is that our estimation methodology captures only changes that occur as a result of demographic changes and not as a result of changes in returns to various features, including racial or ethnic profile.

A key explanation for the lower between-group inequality when using the language partition is, therefore, likely to be a result of the growth in the relative size of the largest linguistic group, the Oshiwambo-speaking households, whose share of the total population has increased from 44 per cent in 1992/1993 to 48 per cent in 2003/2004. While it is not immediately clear why the population dynamics in Namibia favour Oshiwambo-speakers, it is expected that when the relative size of one population group increases, more and more inequality for the partition will shift to within that population group.

There has been no discernible change in inequality between regions or an increase in the degree of inequality between urban and rural areas. Moreover, when using the generalised entropy measure, normalised to take into account the number of partitions, the contribution to between-group inequality from the urban/rural partition is one third higher than when using the more conventional between-group measure. Our study thus provides further evidence of the profound and rigid geographic disparities when it comes to poverty and inequality in Namibia. Such disparities have persisted despite National Development Plan targets towards a progressive decentralisation of resources and the devolution of planning, budgeting and spending powers.

\section{CONCLUSIONS}

This paper has presented new and robust estimates of changes in the levels of poverty and inequality in Namibia. Specifically, an extension of the survey matching techniques associated with the literature on small-area estimates was applied to correct for the changes in methodology between two household surveys. The new 'predicted' estimates for household expenditure in 1993/1994 were shown to be robust to the underlying econometric specification conforming to results from other studies. Using the framework of stochastic dominance, the paper has also provided evidence that the incidence of poverty in Namibia has fallen significantly. The implication is that the country appears to be on track to 
meet the first MDG, which targets a halving of the proportion of people living under the national poverty line between 1990 and 2015. However, the results also show that the impact of welfare changes has been uneven among different social groups, and among some groups poverty could actually be worsening. Moreover, poverty reduction has been driven by growth rather than redistribution, as inequality has fallen to a limited, not statistically significant, degree.

Reducing the extremely unequal nature of Namibia's income distribution would enable growth to have a stronger impact on poverty reduction. While the poorest groups have seen important welfare improvements, these have often not been strong enough to lift, in particular, poor people in rural areas out of poverty. Making the growth process in Namibia more pro-poor would require a combination of country-specific public policy measures, including:

- redressing persistent inequalities in access to quality public services, especially health and education;

- accelerating the extremely slow process of land reform and investing in productivity enhancement among small-scale farmers;

- strengthening employment creation, particularly among the youth and especially in labour-intensive sectors such as tourism, transportation and industry;

- spurring value addition in commodity exports (such as diamonds, meat); and

- expanding social protection in ways that promote both equity and efficiency (foe example, reform of the cash transfer system and experimentation with labour guarantee programmes) and are targeted more effectively towards previously excluded groups, especially in the northern and rural areas.

While Namibia has seen a remarkable transition over the past decades, a substantial amount of 'unfinished business' remains in terms of reducing the country's extreme inequality. This is particularly the case when it comes to inequality related to ethnicity, race and geography, where the legacy of Apartheid endures. However, our finding that education plays an increasing role as a determinant of overall inequality should not lead policymakers to abandon further improvements in access to education, especially completion at the secondary level, as a public policy objective in Namibia. Education remains central to reducing poverty and advancing an inclusive social development process, irrespective of the short- to mediumterm impacts on measures of monetary inequality. In the longer term, however, investments in education need to be accompanied by policies and reforms that much more effectively expand opportunities for absorbing a growing number of graduates into higher productivity and better-paid jobs. Good data, and data that are more comparable over time and space, gained from household surveys and other sources will be critical to guide policymakers to achieve those objectives. 


\section{REFERENCES}

Araar, A. (2007). 'Poverty, inequality and stochastic dominance, theory and practice: The case of Burkina Faso', PMMA Working Paper, No. 10176. Poverty and Economic Policy Network.

Araar, A. and Duclos, J.-Y. (2009). DASP: Distributive Analysis for Stata Package. User manual (DASP 2.1).

Laval, PEP, CIRPEE, World Bank and Université Laval.

Atkinson, A.B. (1987). 'On the Measurement of Poverty', Econometrica, 55, 749-764.

Bauer, G. (2001). 'Namibia in the first decade of Independence: how democratic?', Journal of Southern African Studies, 27(1): 33-55.

Bourguignon, F. (2004). 'The poverty-growth-inequality triangle'. Paper presented at the Indian Council for Research on International Economic Relations, New Delhi, 4 February 2004.

Bourguignon, F., Ferreira, F. and Lustig, N. (eds) (2005). The microeconomics of income distribution Dynamics in East Asia and Latin America. New York, NY, World Bank and Oxford University Press.

Central Bureau of Statistics (2008). A review of poverty and inequality in Namibia. Windhoek, National Planning Commission.

Central Bureau of Statistics (2007). National Accounts 2007. Windhoek, National Planning Commission.

Central Bureau of Statistics (2006). 2003/2004 Namibian Household Income and Expenditure Survey.

Windhoek, National Planning Commission.

Central Bureau of Statistics (1996). Living conditions in Namibia 1993/1994: Economic and social indicators from the Namibian Household Income and Expenditure Survey. Windhoek, National Planning Commission.

Christiaensen, L., Lanjouw, P., Luoto, J. and Stifel, D. (2008). 'The reliability of small area estimation prediction methods to track poverty'. Paper presented at the WIDER Conference on Frontiers of Poverty Analysis in Helsinki, 26-27 September 2008.

Cowell, F.A. (1995). Measuring inequality. Hemel Hempstead, Harvester Wheatsheaf.

Datt, G. and Ravallion, M. (1992). 'Growth and redistribution components of changes in poverty measures: A decomposition with application to Brazil and India in the 1980s', Journal of Development Economics, 38(2): 275-295.

Deaton, A. (2003). 'Adjusted Indian poverty estimates for 1999-2000', Economic and Political Weekly, 37(4): 322-326.

Duclos, J.-Y. and Araar, A. (2006). Poverty and equity: Measurement, policy and estimation with DAD. New York and Ottawa, Springer and International Development Research Centre.

Elbers, C., Lanjouw, P. Mistaen, J. and Özler, B. (2008). 'Reinterpreting between-group Inequality', Journal of Economic Inequality, 6(3): 231-245.

Elbers, C., Lanjouw, J.O. and Lanjouw, P. (2003). 'Micro-level Estimation of Poverty and Inequality', Econometrica, 71(1): 355-364.

Foster, J.E., Greer, J. and Thorbecke, E. (1984). 'A class of decomposable poverty measures', Econometrica, 52(3): 761-766.

Foster, J.E. and Shorrocks, A.F. (1988). 'Poverty Orderings and Welfare Dominance', Social Choice Welfare, 5, 179-198. 
Freeman, L. (1991). 'The contradictions of Independence: Namibia in transition', International Journal, 46(4): 687-718.

Hentschel, J., Lanjouw, J., Lanjouw, P. and Poggi, J. (2000). 'Combining census and survey data to trace the spatial dimensions of poverty: A case study of Ecuador', World Bank Economic Review, 14(1): 147-165.

Hoogeveen, J.G. and Özler, B. (2006). 'Poverty and Inequality in post-Apartheid South Africa: 1995-2000', in H. Bhorat and R. Kanbur (eds), Poverty and Policy in Post-Apartheid South Africa. Cape Town, HSRC Press.

Kijima, Y. and Lanjouw, P. (2003). 'Poverty in India during the 1990s: A regional perspective', World Bank Research Working Paper, No. 3141. Washington, DC, World Bank.

Leibbrandt, M., Woolard, I., Finn, A. and Argent, J. (2010). 'Trends in South African Income Distribution and Poverty since the Fall of Apartheid', OECD Social, Employment and Migration Working Paper, No. 101. Paris, OECD Publishing. Levine, S. (2007). Trends in Human Development and Human Poverty in Namibia. Windhoek, UNDP. Levine, S. and Roberts, B. (2008). 'Combined methods in poverty analysis: Lessons from Namibia', International Journal of Multiple Research Methods, 2: 205-221.

Lopez, J.H. (2004). Pro-poor growth: A review of what we know (and of what we don't). Washington, DC, Mimeo, World Bank.

Mcculloch, N., Baulch, B. and Cherel-Robson, M. (2000). 'Poverty, inequality and growth in Zambia during the $1990 s^{\prime}$. Paper presented at the 26th General Conference of The International Association for Research in Income and Wealth in Krakow, 27 August to 2 September 2000.

Melber, H. (2005). 'Namibia's post-colonial socio-economic (non-)transformation: Business as usual?', Nord-Sud Aktuell, 3/4 Quartal: 306-321.

Minot, N. (2007). 'Are Poor, Remote Areas Left Behind in Agricultural Development: The Case of Tanzania', Journal of African Economies, 17(2): 239-276.

National Planning Commission (2004). National Vision 2020. Windhoek, National Planning Commission.

OECD (2008). What are equivalence scales?. Paris, OECD Social Policy Division,

$<$ http://www.oecd.org/eco/productivityandlongtermgrowth/35411111.pdf $>$ (accessed 5 September 2012).

Ravallion, M. and Chen, S. (2003). 'Measuring Pro-Poor Growth', Economics Letters, 78(1): 93-99.

Ravallion, M. (1997). 'Can high-inequality developing countries escape absolute poverty?', Economics Letters, 56(1): 51-57.

Shorrocks, A.F. (1980). 'The class of additively decomposable inequality measures', Econometrica, 48(3): 613-25.

Stifel, D.C. and Christiaensen, L. (2006). 'Tracking poverty over time in the absence of comparable consumption data', World Bank Policy Research Working Paper, No. 3810. Washington, DC, World Bank.

United Nations (2004). Common Country Assessment for Namibia. Windhoek, United Nations Country Team.

Van Der Berg, S., Burger, R., Louw, M. and Yu, D. (2005). 'Trends in poverty and inequality since the political transition', University of Stellenbosch Economic Working Paper, No. 01/2005. Stellenbosch, University of Stellenbosch.

World Bank (2005). 'Namibia human capital and knowledge development for economic growth with equity', Africa Region Human Development Working Paper Series, No. 84. Washington, DC, World Bank.

World Bank (1993). Namibia: Poverty alleviation with sustainable growth. Washington, DC, World Bank. 


\section{APPENDIX}

Appendix Table A. Summary statistics for NHIES 1993/1994 and 2003/2004

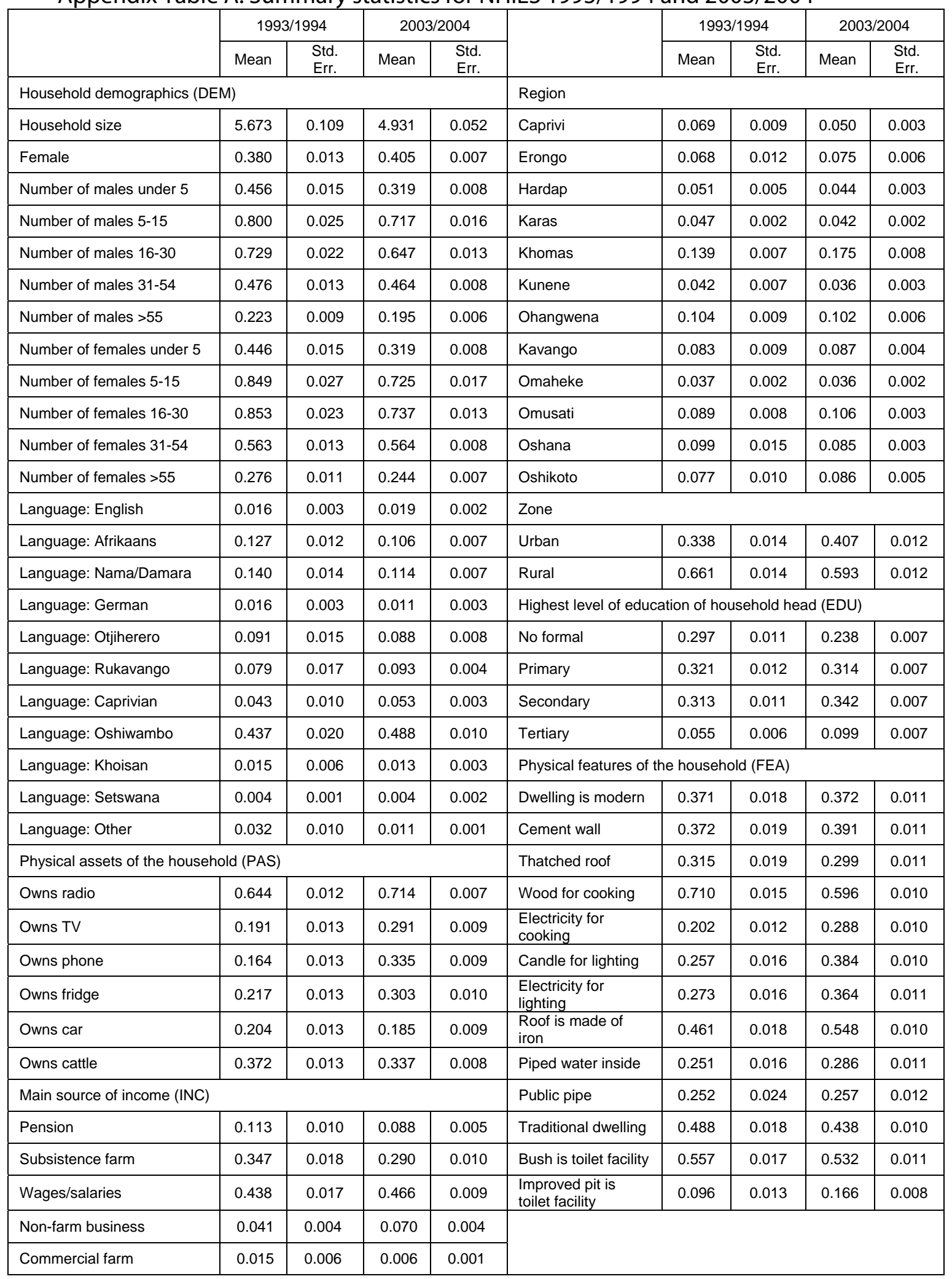


Appendix Table B. Multivariate models of log of per capita consumption expenditure (WITH ALL VARIABLES)

\begin{tabular}{|c|c|c|c|c|c|c|c|c|c|c|c|c|c|}
\hline & 1 & 2 & 3 & 4 & 5 & 6 & 7 & 8 & 9 & 10 & 11 & 12 & 13 \\
\hline Model Stratum: & $\begin{array}{c}\text { Urban } \\
\text { Kavango }\end{array}$ & $\begin{array}{c}\text { Urban } \\
\text { Ohangwena }\end{array}$ & $\begin{array}{l}\text { Urban } \\
\text { Oshikoto }\end{array}$ & $\begin{array}{c}\text { Urban } \\
\text { Hardap }\end{array}$ & $\begin{array}{c}\text { Urban } \\
\text { Omusati }\end{array}$ & $\begin{array}{c}\text { Urban } \\
\text { Omaheke }\end{array}$ & $\begin{array}{l}\text { Urban } \\
\text { Caprivi }\end{array}$ & \begin{tabular}{c|} 
Urban \\
Otjozondjupa
\end{tabular} & $\begin{array}{c}\text { Urban } \\
\text { Kunene }\end{array}$ & $\begin{array}{l}\text { Urban } \\
\text { Karas }\end{array}$ & $\begin{array}{l}\text { Urban } \\
\text { Oshana }\end{array}$ & $\begin{array}{l}\text { Urban } \\
\text { Erongo }\end{array}$ & $\begin{array}{c}\text { Urban } \\
\text { Khomas }\end{array}$ \\
\hline Adj. R-Squared: & 0.7142 & 0.7543 & 0.7526 & 0.7957 & 0.6725 & 0.7905 & 0.5983 & 0.7642 & 0.7420 & 0.7595 & 0.7076 & 0.7563 & 0.7881 \\
\hline NHIES 2003/2004 households: & 265 & 226 & 246 & 248 & 223 & 251 & 280 & 328 & 242 & 345 & 375 & 366 & 927 \\
\hline Model variables and coefficients: & & & & & & & & & & & & & \\
\hline Household size & $-0.150^{\star \star \star}$ & $-0.541^{\star \star \star}$ & $-0.244^{\star \star \star}$ & $-0.284^{\star \star \star}$ & $-0.260^{\star \star \star}$ & $-0.321^{\star \star \star}$ & $-0.312^{\star \star \star}$ & $-0.265^{\star \star \star}$ & $-0.295^{\star \star \star}$ & $-0.341^{\star \star \star}$ & $-0.346^{\star \star \star}$ & $-0.305^{\star \star \star}$ & $-0.359^{\star \star \star}$ \\
\hline Household size squared & $0.007^{\star \star \star}$ & $0.022^{\star \star \star}$ & $0.011^{\star \star \star}$ & $0.016^{\star \star \star}$ & $0.015^{\star \star \star}$ & $0.012^{\star \star \star}$ & $0.016^{\star \star \star}$ & $0.010^{\star \star \star}$ & $0.012^{\star \star \star}$ & $0.017^{\star \star \star}$ & $0.018^{\star \star \star}$ & $0.015^{\star \star \star}$ & $0.018^{\star \star \star}$ \\
\hline Males under 5 years & $-0.175^{\star \star}$ & $0.224^{\star \star}$ & -0.078 & -0.132 & $-0.293^{\star \star}$ & 0.020 & $-0.107^{*}$ & 0.029 & -0.104 & -0.100 & $-0.206^{\star \star}$ & $-0.212^{\star \star \star}$ & -0.005 \\
\hline Females under 5 years & -0.067 & $0.167^{\star}$ & $-0.248^{\star \star}$ & -0.029 & -0.094 & 0.036 & -0.043 & -0.057 & -0.092 & $-0.133^{*}$ & -0.029 & -0.098 & $-0.120^{* \star}$ \\
\hline Males 5-15 years & -0.071 & 0.064 & -0.120 & $-0.131^{\star \star}$ & -0.028 & $-0.125^{*}$ & -0.022 & -0.042 & 0.002 & -0.052 & -0.074 & -0.062 & -0.017 \\
\hline Females 16-30 & -0.088 & 0.060 & -0.044 & -0.032 & -0.120 & -0.076 & -0.047 & -0.048 & -0.047 & -0.007 & -0.025 & 0.060 & -0.024 \\
\hline Males 31-54 & 0.009 & -0.019 & -0.014 & -0.022 & 0.075 & 0.024 & $0.138^{\star}$ & -0.103 & -0.020 & -0.024 & $-0.176^{\star \star \star}$ & -0.033 & -0.057 \\
\hline Females 31-54 & -0.084 & $0.237^{\star \star \star}$ & -0.004 & -0.091 & -0.008 & -0.023 & -0.086 & -0.030 & 0.024 & 0.005 & $0.112^{\star}$ & -0.066 & 0.010 \\
\hline Males over 54 & -0.164 & -0.068 & -0.106 & 0.042 & $-0.896^{\star \star}$ & -0.108 & -0.024 & 0.010 & -0.061 & 0.027 & -0.088 & -0.103 & $-0.176^{* *}$ \\
\hline Females over 54 & $-0.479^{\star \star \star}$ & 0.130 & -0.021 & -0.068 & 0.107 & $-0.315^{*}$ & 0.117 & 0.089 & -0.055 & -0.077 & 0.197 & -0.060 & -0.021 \\
\hline Female headed household & 0.002 & $-0.233^{\star \star}$ & -0.178 & 0.093 & -0.105 & $0.183^{*}$ & 0.045 & -0.044 & -0.048 & -0.107 & $-0.234^{\star \star \star}$ & -0.092 & $-0.160^{* \star \star}$ \\
\hline Age of household head squared & 0.000 & 0.000 & 0.000 & 0.000 & 0.000 & $0.000^{\star \star}$ & 0.000 & 0.000 & 0.000 & $0.000^{\star \star}$ & 0.000 & 0.000 & $0.000^{\star \star}$ \\
\hline Head: No formal education & -0.150 & -0.261 & $-0.318^{\star \star}$ & $-0.384^{\star \star \star}$ & $-0.677^{\star \star \star}$ & $-0.207^{\star}$ & $-0.564^{\star \star \star}$ & $-0.248^{\star \star}$ & $-0.193^{\star}$ & -0.115 & $-0.668^{\star \star \star}$ & -0.022 & $-0.340^{\star \star \star}$ \\
\hline Head: Primary education & -0.127 & 0.133 & $-0.317^{\star \star \star}$ & $-0.238^{\star \star}$ & -0.127 & -0.154 & $-0.282^{\star \star}$ & -0.062 & $-0.145^{\star}$ & $-0.166^{\star \star}$ & $-0.240^{\star \star \star}$ & $-0.124^{*}$ & $-0.163^{\star \star \star}$ \\
\hline Head: Tertiary education & $0.210^{*}$ & $0.237^{\star \star}$ & $0.271^{*}$ & $0.470^{* \star}$ & 0.134 & 0.133 & 0.128 & $0.339^{\star \star \star}$ & 0.373 & 0.110 & $0.208^{\star \star}$ & $0.512^{\star \star \star}$ & $0.385^{\star \star \star}$ \\
\hline Main source of income is wages and salaries & 0.139 & -0.080 & 0.160 & 0.045 & 0.158 & -0.007 & -0.024 & $0.237^{\star \star}$ & $0.160^{*}$ & $0.255^{\star \star}$ & $0.174^{\star \star}$ & $-0.170^{*}$ & 0.046 \\
\hline Main language is Khoisan & & $-2.002^{\star \star}$ & & & & & & $-0.964^{\star \star}$ & -0.037 & & & & \\
\hline Main language is Caprivian & -0.240 & $-0.656^{\star \star}$ & 0.184 & & 0.073 & -0.067 & $-0.495^{\star \star}$ & -0.148 & 0.298 & 0.324 & -0.348 & 0.026 & -0.011 \\
\hline Main language is Otjiherero & 0.199 & & $0.677^{\star \star}$ & -0.343 & -0.071 & 0.112 & -0.508 & -0.069 & 0.134 & 0.424 & 0.207 & 0.072 & -0.075 \\
\hline Main language is Rukavango & -0.263 & & $0.533^{\star \star}$ & -0.236 & & -0.158 & -0.445 & -0.228 & -0.228 & -0.452 & & $-0.001^{\star *}$ & 0.050 \\
\hline Main language is Nama/Damara & & -0.007 & -0.019 & 0.009 & & -0.150 & & $-0.191^{\star \star}$ & $\begin{array}{l}-0.188 \\
\end{array}$ & 0.038 & -0.354 & -0.182 & $-0.171^{\star \star}$ \\
\hline Main language is Setswana & & & & & -0.074 & -0.136 & & 0.531 & & & & & 0.038 \\
\hline Main language is Afrikaans & -0.116 & 0.350 & $0.432^{\star \star \star}$ & 0.034 & 0.103 & 0.126 & & $0.397^{\star \star \star}$ & 0.072 & 0.088 & $0.337^{\star}$ & $0.268^{\star \star \star}$ & 0.092 \\
\hline Main language is German & & 0.536 & $1.036^{\star \star \star}$ & & & & & $0.735^{\star}$ & 0.321 & & & $0.497^{\star \star \star}$ & $0.487^{\star \star \star}$ \\
\hline Main language is English & -0.058 & -0.596 & $1.530^{\star \star \star \star}$ & 0.534 & 0.073 & 0.396 & $-0.613^{*}$ & 0.330 & & $0.665^{\star \star \star}$ & 0.106 & 0.283 & $0.338^{\star \star \star}$ \\
\hline Main language is Other & 0.150 & -0.022 & 0.054 & & 0.330 & -0.324 & $-0.614^{\star}$ & -0.013 & 0.063 & -0.073 & $0.767^{\star \star \star}$ & 0.290 & $0.269^{\star \star}$ \\
\hline Own a radio & $0.184^{\star}$ & $0.171^{\star \star}$ & 0.020 & $0.240^{\star \star}$ & 0.079 & 0.037 & $0.130^{*}$ & $0.224^{\star \star \star}$ & $0.233^{\star \star \star}$ & $0.205^{\star \star}$ & 0.095 & -0.074 & $0.083^{\star}$ \\
\hline Own a television & 0.152 & 0.149 & 0.035 & $0.291^{\star \star \star}$ & 0.160 & $0.247^{\star}$ & 0.128 & $0.188^{\star \star}$ & 0.104 & 0.093 & -0.059 & 0.084 & $0.165^{\star \star \star}$ \\
\hline Own a telephone/cell phone & 0.127 & $0.451^{\star \star \star}$ & $0.609^{\star \star \star}$ & $0.363^{\star \star \star}$ & $0.288^{\star \star \star}$ & 0.097 & $0.175^{\star \star}$ & $0.154^{\star}$ & $0.314^{\star \star \star}$ & $0.392^{\star \star \star}$ & $0.321^{\star \star \star}$ & $0.220^{\star \star \star}$ & $0.215^{\star \star \star}$ \\
\hline Own a refrigerator & 0.186 & -0.001 & $0.387^{\star \star \star}$ & $0.195^{\star}$ & -0.151 & $0.310^{* *}$ & $0.285^{\star \star \star}$ & 0.106 & $0.177^{\star}$ & $0.172^{\star}$ & 0.103 & 0.069 & $0.208^{\star \star \star}$ \\
\hline nwin a c.ar & $n \Delta 78^{\star \star \star}$ & $n \Delta 5 n^{\star \star \star}$ & $0.373^{\star \star \star}$ & $0.51 n^{\star \star *}$ & $0.541^{\star \star \star}$ & $0.749^{\star \star \star}$ & $0.535^{\star \star \star}$ & $0.413^{\star \star \star}$ & $0.487^{\star \star \star}$ & $0.635^{\star \star \star}$ & $0.478^{\star \star \star}$ & $0.506^{\star \star \star}$ & $0.613^{\star \star \star}$ \\
\hline & & & & & & 0.130 & -0.003 & 0.066 & $0.139^{\star}$ & 0.003 & $0.174^{\star \star}$ & $0.190^{\star \star}$ & 0.061 \\
\hline |vivuerII uweminty & 0.100 & 0.150 & -0.103 & - -u.uso & -0.131 & 0.326 & 0.253 & 0.029 & 0.108 & 0.171 & 0.183 & $0.344^{\star \star}$ & 0.076 \\
\hline Traditional dwelling & 0.166 & 0.166 & & & 0.231 & & -0.121 & & 0.048 & 0.622 & 0.389 & & 0.288 \\
\hline Improvised dwelling & 0.127 & 0.098 & -0.583 & -0.136 & -0.249 & 0.279 & -0.032 & -0.380 & 0.031 & 0.206 & $0.414^{\star \star \star}$ & 0.054 & $-0.280^{*}$ \\
\hline
\end{tabular}




\begin{tabular}{|c|c|c|c|c|c|c|c|c|c|c|c|c|c|}
\hline Thatched roof & $-0.581^{\star \star \star}$ & -0.188 & & & & & 0.191 & & 0.357 & & -0.350 & & -0.042 \\
\hline Corrugated iron roof & -0.143 & 0.000 & 0.275 & -0.124 & 0.145 & 0.100 & 0.083 & -0.025 & $0.259^{\star}$ & $-0.345^{\star \star \star}$ & $-0.401^{\star \star}$ & $-0.171^{\star \star}$ & $-0.186^{\star \star}$ \\
\hline Cement wall & -0.056 & 0.031 & -0.306 & -0.029 & 0.186 & 0.238 & 0.020 & -0.003 & -0.161 & -0.115 & $0.269^{\star \star}$ & 0.048 & -0.142 \\
\hline Use wood for cooking & -0.030 & -0.134 & -0.120 & -0.297 & -0.043 & -0.162 & -0.025 & $-0.306^{\star \star}$ & -0.114 & $-0.542^{\star \star \star}$ & -0.046 & 0.039 & -0.126 \\
\hline Use electricity for cooking & 0.091 & 0.002 & -0.144 & $-0.328^{*}$ & 0.113 & 0.064 & 0.180 & -0.017 & -0.042 & $-0.157^{\star \star}$ & 0.042 & 0.186 & $-0.211^{\star}$ \\
\hline Use candles for lighting & 0.347 & 0.103 & -0.338 & -0.149 & 0.090 & 0.217 & 0.134 & 0.191 & $0.407^{\star \star \star}$ & 0.074 & -0.076 & -0.284 & -0.080 \\
\hline Use electricity for lighting & 0.336 & $0.416^{\star \star}$ & -0.323 & 0.266 & 0.068 & 0.191 & 0.138 & 0.313 & $0.557^{\star \star \star}$ & 0.196 & $0.294^{\star}$ & 0.105 & 0.143 \\
\hline Main toilet facility is Bush & $0.222^{\star \star}$ & 0.264 & $-1.344^{\star \star \star}$ & $-0.347^{\star \star}$ & -0.050 & -0.243 & -0.156 & -0.046 & -0.184 & -0.171 & $0.181^{*}$ & 0.098 & -0.047 \\
\hline Water source is piped water in dwelling & $0.465^{\star \star \star}$ & 0.176 & $0.203^{\star}$ & $0.287^{*}$ & $0.632^{\star \star \star}$ & 0.043 & 0.011 & 0.127 & -0.049 & 0.104 & $0.231^{\star *}$ & 0.106 & $0.247^{\star \star \star}$ \\
\hline Water source is public pipe & 0.107 & -0.040 & -0.145 & -0.071 & $0.287^{\star}$ & 0.221 & 0.214 & 0.289 & -0.046 & -0.091 & -0.144 & 0.069 & -0.035 \\
\hline Constant & $6.168^{\star \star \star}$ & $6.870^{\star \star \star}$ & $7.055^{\star \star \star}$ & $6.933^{\star \star \star}$ & $6.436^{\star \star \star}$ & $6.084^{\star \star \star}$ & $7.109^{\star \star \star}$ & $6.540^{\star \star \star}$ & $6.192^{\star \star \star}$ & $6.912^{\star \star \star}$ & $7.190^{\star \star \star}$ & $6.947^{\star \star \star}$ & $7.630^{\star \star \star}$ \\
\hline
\end{tabular}

\section{/Table continued}

\begin{tabular}{|c|c|c|c|c|c|c|c|c|c|c|c|c|c|}
\hline & 14 & 15 & 16 & 17 & 18 & 19 & 20 & 21 & 22 & 23 & 24 & 25 & 26 \\
\hline Model Stratum: & $\begin{array}{c}\text { Rural } \\
\text { Kavango }\end{array}$ & $\begin{array}{c}\text { Rural } \\
\text { Ohangwena }\end{array}$ & $\begin{array}{c}\text { Rural } \\
\text { Oshikoto }\end{array}$ & $\begin{array}{l}\text { Rural } \\
\text { Hardap }\end{array}$ & $\begin{array}{c}\text { Rural } \\
\text { Omusati }\end{array}$ & $\begin{array}{c}\text { Rural } \\
\text { Omaheke }\end{array}$ & $\begin{array}{l}\text { Rural } \\
\text { Caprivi }\end{array}$ & \begin{tabular}{c|} 
Rural \\
Otjozondjupa
\end{tabular} & $\begin{array}{c}\text { Rural } \\
\text { Kunene }\end{array}$ & $\begin{array}{l}\text { Rural } \\
\text { Karas }\end{array}$ & $\begin{array}{l}\text { Rural } \\
\text { Oshana }\end{array}$ & $\begin{array}{l}\text { Rural } \\
\text { Erongo }\end{array}$ & $\begin{array}{c}\text { Rural } \\
\text { Khomas }\end{array}$ \\
\hline Adj. R-Squared: & 0.6680 & 0.6274 & 0.6254 & 0.7705 & 0.5087 & 0.7348 & 0.6192 & 0.7867 & 0.7194 & 0.7863 & 0.5430 & 0.8346 & 0.8371 \\
\hline NHIES 2003/2004 households: & 449 & 499 & 752 & 392 & 741 & 244 & 451 & 373 & 236 & 300 & 630 & 179 & 233 \\
\hline \multicolumn{14}{|l|}{ Model variables and coefficients: } \\
\hline Household size & $-0.215^{\star \star \star}$ & $-0.141^{\star \star \star}$ & $-0.192^{\star \star \star}$ & $-0.365^{\star \star \star}$ & $-0.235^{\star \star \star}$ & $-0.271^{\star \star \star}$ & $-0.400^{\star \star \star}$ & $-0.278^{\star \star \star}$ & $-0.362^{\star \star \star}$ & $-0.313^{\star \star \star}$ & $-0.174^{\star \star \star}$ & $-0.298^{\star \star \star}$ & $-0.316^{\star \star \star}$ \\
\hline Household size squared & $0.009^{\star \star \star}$ & $0.006^{* \star \star}$ & $0.009^{\star \star \star *}$ & $0.018^{\star \star \star}$ & $0.010^{\star \star \star}$ & $0.013^{\star \star \star}$ & $0.026^{\star \star \star}$ & $0.014^{\star \star \star}$ & $0.015^{\star \star \star}$ & $0.015^{\star \star \star}$ & $0.006^{\star \star \star}$ & $0.022^{\star \star \star}$ & $0.023^{\star \star \star}$ \\
\hline Males under 5 years & -0.060 & $-0.103^{\star \star \star}$ & $-0.162^{\star \star *}$ & -0.017 & -0.050 & -0.033 & $-0.138^{\star \star \star}$ & -0.086 & -0.056 & $-0.177^{*}$ & -0.007 & -0.032 & -0.130 \\
\hline Females under 5 years & -0.034 & $-0.080^{\star \star}$ & -0.038 & 0.003 & $-0.102^{\star \star \star}$ & 0.011 & -0.077 & $-0.138^{\star \star}$ & 0.035 & -0.104 & $-0.067^{\star}$ & -0.184 & -0.129 \\
\hline Males 5-15 years & $-0.065^{\star}$ & -0.046 & $-0.049^{*}$ & -0.029 & -0.028 & -0.079 & $-0.117^{\star \star \star}$ & -0.051 & -0.046 & -0.103 & $-0.079^{\star \star \star}$ & $-0.244^{\star \star}$ & -0.130 \\
\hline Females 16-30 & -0.033 & -0.019 & 0.009 & -0.040 & 0.009 & $-0.175^{\star}$ & -0.065 & -0.012 & 0.074 & 0.011 & 0.002 & -0.079 & -0.011 \\
\hline Males 31-54 & -0.058 & -0.013 & $-0.131^{\star \star \star}$ & -0.057 & -0.006 & -0.007 & -0.037 & -0.084 & 0.058 & $0.143^{*}$ & 0.060 & -0.011 & 0.025 \\
\hline Females 31-54 & -0.035 & -0.002 & -0.015 & $-0.165^{\star}$ & 0.042 & -0.174 & -0.013 & 0.016 & -0.043 & 0.009 & -0.011 & -0.118 & -0.005 \\
\hline Males over 54 & $-0.314^{\star \star \star}$ & $-0.095^{\star}$ & -0.063 & -0.043 & -0.105 & 0.144 & -0.026 & -0.163 & -0.154 & $-0.205^{\star}$ & 0.067 & -0.027 & $-0.257^{\star}$ \\
\hline Females over 54 & $-0.146^{*}$ & -0.044 & 0.014 & 0.005 & -0.003 & -0.152 & $0.165^{\star}$ & 0.077 & -0.017 & 0.072 & -0.058 & $-0.354^{\star \star}$ & 0.087 \\
\hline Female headed household & $-0.152^{\star \star}$ & $-0.106^{*}$ & $-0.102^{\star}$ & -0.121 & -0.042 & -0.190 & 0.030 & $-0.265^{\star \star \star}$ & -0.034 & -0.040 & 0.037 & 0.134 & 0.049 \\
\hline Age of household head squared & $0.000^{\star \star \star}$ & 0.000 & 0.000 & 0.000 & $0.000^{\star \star \star}$ & 0.000 & 0.000 & 0.000 & $0.000^{\star \star}$ & 0.000 & 0.000 & 0.000 & $0.000^{\star *}$ \\
\hline Head: No formal education & -0.092 & $-0.182^{\star \star \star}$ & $-0.253^{\star \star \star}$ & -0.129 & $-0.159^{\star \star}$ & $-0.215^{*}$ & $-0.226^{\star \star \star}$ & $-0.316^{\star \star \star}$ & -0.196 & -0.119 & -0.085 & $-0.326^{\star \star}$ & $-0.315^{\star \star}$ \\
\hline Head: Primary education & -0.091 & $-0.117^{\star}$ & $-0.172^{\star \star \star}$ & $-0.151^{\star}$ & -0.060 & $-0.234^{\star}$ & $-0.194^{\star \star \star}$ & $-0.219^{\star \star}$ & -0.083 & 0.000 & -0.003 & -0.106 & $-0.413^{\star \star \star}$ \\
\hline Head: Tertiary education & $0.496^{\star \star \star}$ & $0.429^{\star \star \star}$ & $0.299^{\star \star \star}$ & $0.668^{\star \star \star}$ & $0.429^{\star \star \star}$ & 0.276 & $0.488^{\star \star \star}$ & 0.204 & $0.682^{\star \star \star}$ & $0.720^{\star \star \star}$ & $0.347^{\star \star \star}$ & $0.811^{\star \star \star}$ & $0.884^{\star \star \star}$ \\
\hline \multicolumn{14}{|l|}{ Main source of income is wages an } \\
\hline \multicolumn{14}{|l|}{ Main language is Khoisan } \\
\hline Main language is Caprivian & $-1.500 \cdots$ & $0 .<10$ & u.J30 & U.ง כ & $-u .<s u$ & & $-\angle . \cup u J \cdots \cdots \cdot$. & $-u . s<u$ & u.sy1 & 0.450 & & & \\
\hline Main language is Otjiherero & -0.601 & 0.649 & -0.053 & -0.076 & 0.171 & 0.160 & & $0.181^{*}$ & 0.032 & -0.874 & & 0.029 & 0.232 \\
\hline Main language is Rukavango & $-0.395^{\star}$ & & -0.302 & -0.475 & 0.244 & -0.631 & $-2.150^{\star \star \star}$ & 0.030 & 0.057 & 0.228 & & 0.364 & -0.139 \\
\hline Main language is Nama/Damara & -0.785 & & $-0.259^{\star}$ & -0.282 & -0.280 & -0.052 & & 0.080 & -0.288 & 0.067 & & -0.082 & $-0.308^{\star \star}$ \\
\hline
\end{tabular}




\begin{tabular}{|c|c|c|c|c|c|c|c|c|c|c|c|c|c|}
\hline Main language is Setswana & & & & -0.417 & & 0.000 & & $\mid-0.164$ & & & & & -0.585 \\
\hline Main language is Afrikaans & 0.222 & 0.089 & 0.321 & -0.092 & & \begin{tabular}{l|l}
0.492 & \\
\end{tabular} & & $0.514^{\star \star \star}$ & -0.172 & 0.150 & & $0.413^{*}$ & -0.056 \\
\hline Main language is German & & & 0.694 & 0.561 & & 0.526 & & $1.250^{\star \star \star}$ & -0.621 & -0.219 & & $0.913^{* \star}$ & -0.033 \\
\hline Main language is English & & & -0.185 & -0.439 & -0.392 & & $-1.661^{\star \star}$ & & 0.857 & 0.486 & & $1.198^{\star \star \star}$ & -0.119 \\
\hline Main language is Other & -0.467 & 0.001 & & 0.248 & $-0.385^{*}$ & & $-1.926^{\star \star \star}$ & -0.387 & & \begin{tabular}{l|l}
1.040 & \\
\end{tabular} & 0.171 & & $0.620^{*}$ \\
\hline Own a television & 0.126 & -0.046 & $0.228^{\star \star}$ & $0.392^{\star \star \star}$ & 0.045 & 0.013 & $0.239^{\star \star \star}$ & 0.062 & -0.056 & 0.190 & 0.008 & 0.601 & -0.037 \\
\hline Own a telephone/cellphone & $0.349^{\star \star}$ & $0.342^{\star \star \star}$ & $0.235^{\star \star \star}$ & $0.588^{\star \star \star}$ & $0.309^{\star \star \star}$ & $0.390^{\star \star}$ & -0.067 & $0.216^{\star}$ & $0.271^{\star}$ & $0.307^{\star \star}$ & $0.234^{\star \star \star}$ & $0.213^{\star \star \star}$ & 0.098 \\
\hline Own a refrigerator & $-0.879^{* \star \star}$ & $0.285^{*}$ & 0.126 & 0.165 & $0.314^{\star \star}$ & $0.494^{\star \star \star}$ & $0.250^{* *}$ & -0.023 & 0.129 & $0.259^{*}$ & $0.214^{\star \star}$ & 0.062 & 0.209 \\
\hline Own a car & $0.853^{\star \star \star}$ & $0.221^{*}$ & $0.459^{\star \star \star}$ & $0.421^{\star \star \star}$ & $0.466^{\star \star \star}$ & $0.638^{\star \star \star}$ & $0.569^{\star \star \star}$ & $0.492^{\star \star \star}$ & $0.352^{\star \star}$ & $0.530^{\star \star \star}$ & $0.464^{\star \star \star}$ & $0.542^{\star \star \star}$ & $0.940^{\star \star \star}$ \\
\hline Own cattle & $0.292^{\star \star \star}$ & $0.148^{\star \star \star}$ & $0.141^{\star \star \star}$ & $0.519^{\star \star \star}$ & $0.158^{\star \star \star}$ & $0.402^{\star \star \star}$ & $0.234^{\star \star \star}$ & $0.430^{\star \star \star}$ & $0.249^{\star \star \star}$ & $0.278^{\star \star}$ & $0.123^{\star \star \star}$ & $0.502^{\star \star \star}$ & 0.054 \\
\hline Traditional dwelling & 0.450 & 0.434 & -0.144 & 0.035 & 0.034 & -0.083 & 0.031 & $-0.392^{\star \star}$ & -0.274 & 0.176 & -0.455 & -0.392 & -0.372 \\
\hline Improvised dwelling & 0.515 & $0.580^{*}$ & -0.273 & -0.339 & -0.041 & -0.205 & -0.614 & $-0.366^{\star \star}$ & -0.059 & -0.064 & -0.451 & -0.555 & -0.101 \\
\hline Thatched roof & $-0.145^{\star \star}$ & -0.146 & 0.142 & & 0.001 & $1.211^{\star \star}$ & -0.103 & -0.093 & 0.113 & 0.195 & -0.065 & & $1.658^{\star \star \star}$ \\
\hline Corrugated iron roof & 0.031 & -0.115 & 0.033 & $0.282^{\star}$ & 0.150 & $0.600^{\star \star}$ & 0.084 & 0.008 & 0.012 & 0.233 & -0.033 & -0.044 & 0.157 \\
\hline Cement wall & 0.265 & 0.037 & 0.088 & 0.020 & -0.128 & -0.063 & 0.131 & 0.085 & $0.306^{*}$ & -0.111 & 0.024 & $0.440^{\star \star \star}$ & 0.159 \\
\hline Use wood for cooking & 0.024 & $0.407^{\star \star \star}$ & 0.033 & -0.148 & -0.066 & -0.114 & -0.090 & -0.307 & $-0.781^{\star \star}$ & $-0.442^{\star \star \star}$ & $-0.111^{\star \star}$ & $-0.488^{\star \star}$ & -0.187 \\
\hline Use electricity for cooking & -0.386 & $1.842^{\star \star \star}$ & 0.120 & -0.201 & -0.263 & -0.286 & 0.518 & -0.052 & $-0.783^{\star \star}$ & -0.090 & $0.459^{\star \star}$ & -0.282 & -0.009 \\
\hline Use candles for lighting & $0.127^{\star \star}$ & 0.063 & 0.028 & 0.079 & $0.140^{\star \star \star}$ & 0.116 & -0.048 & $0.164^{\star}$ & -0.096 & -0.085 & -0.034 & 0.328 & $-0.216^{\star}$ \\
\hline Use electricity for lighting & $0.606^{\star \star}$ & $-0.855^{\star}$ & 0.105 & -0.030 & 0.154 & -0.045 & -0.025 & 0.151 & -0.037 & -0.164 & -0.181 & $0.094^{\star \star}$ & -0.163 \\
\hline Main toilet facility is Bush & $-0.450^{\star \star}$ & -0.093 & $-0.106^{*}$ & -0.140 & $-0.131^{*}$ & -0.019 & -0.212 & $-0.152^{*}$ & $-0.254^{\star \star}$ & 0.018 & -0.057 & -0.135 & $-0.380^{\star \star \star}$ \\
\hline Constant & $6.589^{\star \star \star}$ & $5.711^{\star \star \star}$ & $6.424^{\star \star \star}$ & $7.262^{\star \star \star}$ & $6.429^{\star \star \star}$ & $6.403^{\star \star \star}$ & $9.239^{\star \star \star}$ & $7.124^{\star \star \star}$ & $8.049^{\star \star \star}$ & $6.792^{\star \star \star}$ & $6.951^{\star \star \star}$ & $7.231^{\star \star \star}$ & $7.448^{\star \star \star}$ \\
\hline
\end{tabular}

Note: * indicates that coefficient is significant at the 10 per cent level, ${ }^{* *}$ at the 5 per cent level, and ${ }^{* *}$ at the 1 per cent level. 


\section{NOTES}

1. GDP per capita in constant 2005 US\$ PPP was US\$5807 for Namibia and US\$2044 for sub-Saharan Africa in 2010 according to the online version of the World Development Indicators (accessed June 2011).

2. Growth in GDP per capita averaged 2 per cent over the decade 1995-2005 (Central Bureau of Statistics, 2007).

3. Disaggregated models were justified through Chow tests.

4. There are 26 strata in the NHIES 2003/2004, given that urban households in both Ohangwena and Omusati were incorporated in the sample, signifying that 26 regression models were estimated. However, in predicting 1993/94 per capita monthly expenditure, we ultimately relied on 24 models. This desegregated estimation produces more refined models and reduces the presence of heteroscedasticity. The Breusch-Pagan/Cook-Weisberg test suggested that eight of the 26 models exhibited heteroscedasticity, and these were estimated using STATA's robust command.

5. We also estimated the counter-factual welfare distribution for 1993/1994 using just one 'big' regression model with regional dummies. We found no statistical difference between these estimates of poverty and the estimates produced directly from the 2003/2004 survey and those generated by predicting 2003/2004 welfare using the model. However, the regression results reveal significant degrees of heteroscedasticity, which is reduced when using the disaggregated models as described in the text. These results are not reported here but are available upon request from the authors.

6. This scale is defined in Central Bureau of Statistics (2008) as: $1^{*} n(>16)+0.5^{*} n(0-5)+0.75^{*} n(6-15)$, where $n$ refers to the number of household members in that age group. We check our result using two alternative scales: one that weighs all members equally (per capita) and one that uses the scale proposed by OECD (2008), which is: $1+0.7^{*}(\mathrm{n}(>16)-1)+$ $0.5^{*} \mathrm{n}(0-15)$. Using different scales has implications: for instance, using per capita raises levels of poverty compared to the scale used by the statistics office and, in particular, OECD. However, the directions of change and the general conclusions of our results are robust to differences in the specifications of the adult equivalence scales.

7. We also ran alternative specifications of the decomposition, first reversing the reference periods in (6) and (7) and then using the Shapely approach, which eliminates the residual (Duclos and Araar, 2006). Conclusions were unchanged.

8. The generalised entropy indices satisfy a number of important principles, including mean independence, population size independence and the Pigou-Dalton principle of transfers (Shorrocks, 1980).

9. In practice, maximum between-group inequality is computed by replacing the rank-ordered sub-group mean of adult equivalent household consumption expenditure, by the mean generated by rank ordering the population according to the same relative shares as the sub-group partitions.

10. We implement these procedures using the Distributive Analysis for STATA Package described in Araar and Duclos (2009). 11. It should be noted that these results refer to the sex of the head of household, and - like all the results presented in this paper - they do not reflect potentially important intra-household inequalities.

12. One suggested option would be to create a 'white'/'non-white' distinction by combining English, German and Afrikaans-speakers into one group, but this would obscure due to the fact that many people of mixed race (referred to as 'coloureds' in South Africa) use the Afrikaans language.

13. Since the inequality estimates were found to be robust to the empirical estimation of the 1992/1993 expenditure, only estimates for the full specification of Equation 1 are presented. 


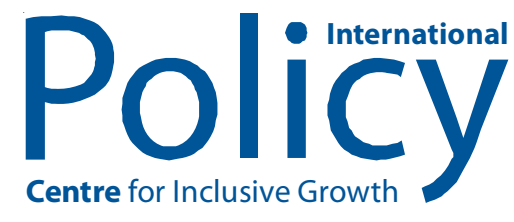

International Policy Centre for Inclusive Growth (IPC - IG)

Poverty Practice, Bureau for Development Policy, UNDP

Esplanada dos Ministérios, Bloco O, $7^{\circ}$ andar

70052-900 Brasilia, DF - Brazil

Telephone: +55 6121055000

E-mail: ipc@ipc-undp.org • URL: www.ipc-undp.org 